\title{
Increasing ozone in marine boundary layer inflow at the west coasts of North America and Europe
}

\author{
D. D. Parrish ${ }^{1}$, D. B. Millet ${ }^{2}$, and A. H. Goldstein ${ }^{3}$ \\ ${ }^{1}$ NOAA Earth System Research Laboratory, Chemical Sciences Division, 325 Broadway R/CSD7, Boulder, CO 80305, USA \\ ${ }^{2}$ Department of Soil, Water \& Climate, University of Minnesota, St. Paul, MN, USA \\ ${ }^{3}$ Department of Environmental Science, Policy, and Management, University of California, Berkeley, CA, USA
}

Received: 9 June 2008 - Published in Atmos. Chem. Phys. Discuss.: 22 July 2008

Revised: 26 January 2009 - Accepted: 26 January 2009 - Published: 19 February 2009

\begin{abstract}
An effective method is presented for determining the ozone $\left(\mathrm{O}_{3}\right)$ mixing ratio in the onshore flow of marine air at the North American west coast. By combining the data available from all marine boundary layer (MBL) sites with simultaneous wind data, decadal temporal trends of MBL $\mathrm{O}_{3}$ in all seasons are established with high precision. The average springtime temporal trend over the past two decades is $0.46 \mathrm{ppbv} / \mathrm{yr}$ with a $95 \%$ confidence limit of $0.13 \mathrm{ppbv} / \mathrm{yr}$, and statistically significant trends are found for all seasons except autumn, which does have a significantly smaller trend than other seasons. The average trend in mean annual ozone is $0.34 \pm 0.09 \mathrm{ppbv} / \mathrm{yr}$. These decadal trends at the North American west coast present a striking comparison and contrast with the trends reported for the European west coast at Mace Head, Ireland. The trends in the winter, spring and summer seasons compare well at the two locations, while the Mace Head trend is significantly greater in autumn. Even though the trends are similar, the absolute $\mathrm{O}_{3}$ mixing ratios differ markedly, with the marine air arriving at Europe in all seasons containing $7 \pm 2$ ppbv higher ozone than marine air arriving at North America. Further, the ozone mixing ratios at the North American west coast show no indication of stabilizing as has been reported for Mace Head. In a larger historical context the background boundary layer $\mathrm{O}_{3}$ mixing ratios over the 130 years covered by available data have increased substantially (by a factor of two to three), and this increase continues at present, at least in the MBL of the Pacific coast region of North America. The reproduction of the increasing trends in $\mathrm{MBL} \mathrm{O}_{3}$ over the past two decades, as well as the difference in the $\mathrm{O}_{3}$ mixing ratios between the
\end{abstract}

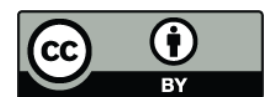

Correspondence to: D. D. Parrish (david.d.parrish@noaa.gov) two coastal regions will present a significant challenge for global chemical transport models. Further, the ability of the models to at least semi-quantitatively reproduce the longerterm, historical trends may an even greater challenge.

\section{Introduction}

Reliably establishing the temporal trends of background $\mathrm{O}_{3}$ in the northern mid latitudes is very important to our understanding of the budget of tropospheric $\mathrm{O}_{3}$. (Here we use the term "background $\mathrm{O}_{3}$ " to qualitatively describe $\mathrm{O}_{3}$ mixing ratios measured at a given site in the absence of strong local effects. Different publications have used different quantitative definitions; in the following sections we develop the quantitative definition used in this work.) The majority of anthropogenic precursors of $\mathrm{O}_{3}$ are emitted at northern mid latitudes, and these emissions have increased over the last century, most dramatically beginning around 1950 (van Aardenne et al., 2001). This increase began first over North America and Europe, and more recently has accelerated over Asia. In about 1970 emissions from Europe and North America began to stabilize and since have decreased (RETRO, 2007). This decrease has been significantly more rapid for volatile organic carbon species than for the oxides of nitrogen, particularly in North America. In contrast emissions from Asia continue to increase (RETRO, 2007). The ability of global chemical transport models to reproduce changes in tropospheric $\mathrm{O}_{3}$ that have occurred in response to these emission changes is an important test for these models (e.g. Fusco and Logan, 2003). Indeed, Activity 1 of the WCRP-SPARC and IGBP-IGAC initiative - Atmospheric Chemistry and Climate - comprises a 20-25 year hindcast of tropospheric $\mathrm{O}_{3}$

Published by Copernicus Publications on behalf of the European Geosciences Union. 
and aerosols. However, for such tests to achieve maximum success it is critical that analyses of field observations characterize the temporal trends of the tropospheric $\mathrm{O}_{3}$ mixing ratios as accurately and precisely as possible.

Establishing the temporal trends and the absolute magnitude of background $\mathrm{O}_{3}$ is also important from the perspective of local and regional air quality control. The $\mathrm{O}_{3}$ transported into a region determines how much locally produced $\mathrm{O}_{3}$ can be added before exceeding air quality standards. As peak $\mathrm{O}_{3}$ is decreased due to local and regional air pollution control measures, the background $\mathrm{O}_{3}$ becomes even more important when considering the potential efficacy of future air pollution control measures. Also, increasing background $\mathrm{O}_{3}$ can offset the benefits of these local and regional control measures (e.g., Jacob et al., 1999).

The earliest trend analyses of $\mathrm{O}_{3}$ that were based upon techniques thought to yield reliable results (Volz and Kley, 1988; Staehelin et al., 1994) indicated that $\mathrm{O}_{3}$ increased by at least a factor of two in near-surface air at suburban to remote regions of Europe between the late 1800s and the early 1980s. There is concern regarding the confidence that can be placed in these early measurements, but considerable effort was put into maximizing this confidence. More recent trend analyses, as summarized by Oltmans et al. (2006), have found significant regional differences, and no consistent increase or decrease in tropospheric $\mathrm{O}_{3}$ has been established, particularly for the northern mid latitudes.

Over continents competing effects make it difficult to characterize background $\mathrm{O}_{3}$. Fiore et al. (2002) conclude that over North America the observed decrease in the high end of the $\mathrm{O}_{3}$ probability distribution in surface air over the United States reflects reduction of domestic hydrocarbon emissions, while the increase in the low end reflects, at least in their model, rising Asian emissions. The $\mathrm{O}_{3}$ trends over the 19872004 time period at nine rural sites in the western continental United States (Jaffe and Ray, 2007) varied between 0 and $0.51 \mathrm{ppbv} / \mathrm{yr}$ with a statistically significant positive trend at seven of the nine sites. The impact of transport events bringing diluted plumes of urban origin with $\mathrm{O}_{3}$ from the high end of the probability distribution likely varies between the nine sites, and thus plays a significant role in the large variability in these temporal trends. One goal of the present analysis is to avoid the impact of transported plumes of $\mathrm{O}_{3}$ produced locally in order to characterize the temporal trend of background $\mathrm{O}_{3}$ transported into the region.

Two particularly important locations to characterize $\mathrm{O}_{3}$ trends are at the downwind side of the North Pacific and North Atlantic Oceans. These downwind locations receive air representing a regional integration over outflow from wide regions of the upwind continents. The $\mathrm{O}_{3}$ mixing ratios in continental outflow are modified by the interaction of transport, mixing and $\mathrm{O}_{3}$ production and loss processes during transport through the marine environment. With only limited emission sources and minimal $\mathrm{O}_{3}$ deposition within the marine environment, mixing and chemical processes tend to reduce the variability of the marine $\mathrm{O}_{3}$. The observed variability of $\mathrm{O}_{3}$ in marine air received on the downwind coast largely reflects variability of large-scale flow patterns of the transported air masses. Measurements within the marine air inflow also provide the potential to sample $\mathrm{O}_{3}$ in an environment without dominant confounding continental influences such as in situ $\mathrm{O}_{3}$ production from locally emitted precursors, transport of air masses with widely varying histories, surface deposition, reaction of $\mathrm{O}_{3}$ with local emissions, etc. Temporal changes in these influences undoubtedly contribute to the significant regional differences found in $\mathrm{O}_{3}$ trends at northern mid latitudes (Oltmans et al., 2006; Jaffe and Ray, 2007). If trends in background $\mathrm{O}_{3}$ can be established for the downwind sides of the two large oceans at northern mid latitudes, then they are likely of more fundamental importance to our understanding of the background tropospheric $\mathrm{O}_{3}$ budget than are the variable regional trends over the continents. However, to characterize these marine trends from land surface based measurements requires careful discrimination against continental effects in the analysis of the available data sets. Our goal in this paper is to characterize these temporal trends in the boundary layer of these two marine environments.

Investigators have presented evidence that the background $\mathrm{O}_{3}$ has increased since the mid-1980s at northern mid latitudes in air entering both the North American west coast form the North Pacific Ocean (Jaffe et al., 2003; Parrish et al., 2004a) and the European west coast from the North Atlantic Ocean (Simmonds et al., 2004; Derwent et al., 2007). Parrish et al. (2004a) argue that the increase in the North Pacific has occurred in response to increasing Asian emissions of $\mathrm{O}_{3}$ precursors, which are transported to the North Pacific troposphere. However, other investigators (Oltmans et al., 2006, 2008) have suggested that the reported increase at the North American west coast was actually caused by local North American continental effects rather than representing an increase in the background marine $\mathrm{O}_{3}$. A resolution to this disagreement is important for establishing the confidence that can be attached to the reported marine $\mathrm{O}_{3}$ trends.

In an effort to reach a resolution of this disagreement, the first goal of this paper is to comprehensively review the available observations and analyses that provide the basis for determining the $\mathrm{O}_{3}$ temporal trend at the North American west coast, and to define that temporal trend as accurately and precisely as possible. Jaffe et al. (2003) and Parrish et al. (2004a) presented trend determinations based on three different data sets: first, several relatively short-term measurement records from different MBL sites that spanned 18 years; second, one continuous 15-year record from Lassen Volcanic National Park; and third, two aircraft campaigns conducted over the eastern North Pacific 18 years apart. All three of the derived trends are consistent with each other and indicate a springtime (the season of the focus of those studies) increase of $0.5 \mathrm{ppbv} / \mathrm{yr}$. The focus of this paper is on all of west coast, North American MBL data that have been collected with the 
Table 1. Ozone data sets investigated in the present analysis.

\begin{tabular}{|c|c|c|c|c|}
\hline Monitoring Site & Dates & Lat./Long. & Elevation (m) & Data Source \\
\hline $\begin{array}{l}\text { Cheeka Peak, } \\
\text { Washington }\end{array}$ & $\begin{array}{l}\text { Springtime, } \\
1997 \text { to } 2002\end{array}$ & $\begin{array}{l}48^{\circ} 18^{\prime} \mathrm{N} \\
124^{\circ} 36^{\prime} \mathrm{W}\end{array}$ & 480 & Jaffe et al., 2003 \\
\hline $\begin{array}{l}\text { Olympic N.P., } \\
\text { Washington }\end{array}$ & $\begin{array}{l}\text { November 1981- } \\
\text { February } 2005\end{array}$ & $\begin{array}{l}48^{\circ} 7^{\prime} \mathrm{N} \\
123^{\circ} 26^{\prime} \mathrm{W}\end{array}$ & 125 & $\begin{array}{l}\text { National Park Service, } \\
\text { Air Resources Division }\end{array}$ \\
\hline $\begin{array}{l}\text { Quillayute, } \\
\text { Washington }\end{array}$ & $\begin{array}{l}\text { January } 1974- \\
\text { July } 1975\end{array}$ & $\begin{array}{l}47^{\circ} 56^{\prime} \mathrm{N} \\
124^{\circ} 34^{\prime} \mathrm{W}\end{array}$ & 62 & $\begin{array}{l}\text { US Environmental } \\
\text { Protection Agency }\end{array}$ \\
\hline $\begin{array}{l}\text { Yreka, } \\
\text { California }\end{array}$ & $\begin{array}{l}\text { March 1981- } \\
\text { December 2005 }\end{array}$ & $\begin{array}{l}41^{\circ} 44^{\prime} \mathrm{N} \\
122^{\circ} 38^{\prime} \mathrm{W}\end{array}$ & 802 & $\begin{array}{l}\text { California Air } \\
\text { Resources Board }\end{array}$ \\
\hline $\begin{array}{l}\text { Redwood N.P., } \\
\text { California }\end{array}$ & $\begin{array}{l}\text { November 1987- } \\
\text { May } 1995\end{array}$ & $\begin{array}{l}41^{\circ} 34^{\prime} \mathrm{N} \\
124^{\circ} 5^{\prime} \mathrm{W}\end{array}$ & 235 & $\begin{array}{l}\text { National Park Service, } \\
\text { Air Resources Division }\end{array}$ \\
\hline $\begin{array}{l}\text { Trinidad Head, } \\
\text { California }\end{array}$ & $\begin{array}{l}\text { April } 2002 \text { to } \\
\text { December } 2007\end{array}$ & $\begin{array}{l}41^{\circ} 3^{\prime} \mathrm{N} \\
124^{\circ} 9^{\prime} \mathrm{W}\end{array}$ & 100 & $\begin{array}{l}\text { Goldstein et al., 2004; } \\
\text { NOAA GMD }\end{array}$ \\
\hline $\begin{array}{l}\text { Point Arena, } \\
\text { California }\end{array}$ & $\begin{array}{l}24 \text { April- } \\
5 \text { May } 1985\end{array}$ & $\begin{array}{l}38^{\circ} 57^{\prime} \mathrm{N} \\
123^{\circ} 44^{\prime} \mathrm{W}\end{array}$ & 20 & Parrish et al., 1992 \\
\hline $\begin{array}{l}\text { Point Reyes N.S., } \\
\text { California }\end{array}$ & $\begin{array}{l}\text { November 1987- } \\
\text { December } 1992\end{array}$ & $\begin{array}{l}38^{\circ} 7^{\prime} \mathrm{N} \\
122^{\circ} 55^{\prime} \mathrm{W}\end{array}$ & 76 & $\begin{array}{l}\text { National Park Service, } \\
\text { Air Resources Division }\end{array}$ \\
\hline $\begin{array}{l}\text { Channel Islands N.P., } \\
\text { California }\end{array}$ & $\begin{array}{l}\text { January 1997- } \\
\text { December } 2004\end{array}$ & $\begin{array}{l}34^{\circ} 1^{\prime} \mathrm{N} \\
120^{\circ} 3^{\prime} \mathrm{W}\end{array}$ & 0 & $\begin{array}{l}\text { National Park Service, } \\
\text { Air Resources Division }\end{array}$ \\
\hline
\end{tabular}

a National Oceanic and Atmospheric Administration, Earth System Research Laboratory, Global Monitoring Division

goal to carefully examine trends in all seasons, and to evaluate the suggestions of Oltmans et al. $(2006,2008)$ that the previously derived trends do not represent the marine troposphere. We find results here that are fully consistent with the conclusions presented by Jaffe et al. (2003) and Parrish et al. (2004a), with the statistical confidence considerably improved. It is shown that the data sets on which Oltmans et al. $(2006,2008)$ based their suggestions have serious shortcomings. A future paper will examine data from higher elevation, inland sites that receive direct inflow of marine air, including Lassen Volcanic National Park, and data sets collected from aircraft and sondes; preliminary analysis of these data supports the trends found by Jaffe et al. (2003) and Parrish et al. (2004a) as well.

The second goal of this paper is to place the derived North American west coast $\mathrm{MBL} \mathrm{O}_{3}$ trends into a larger spatial and historical context by comparing them with reported European tropospheric $\mathrm{O}_{3}$ trends. An increasing trend over the past two decades has been well established at Mace Head, Ireland (Simmonds et al., 2004; Derwent et al., 2007). We will show that the trends of MBL $\mathrm{O}_{3}$ at the west coast of North America have some marked similarities to and marked differences from these European trends.

This paper is organized as follows. Section 2 reviews all of the MBL $\mathrm{O}_{3}$ data that have been collected on the North American west coast and that have been suggested as suitable for characterizing background $\mathrm{O}_{3}$. Section 3 discusses in detail the analysis that is required to characterize marine $\mathrm{O}_{3}$ from measurements conducted at land-based sites receiving direct MBL inflow. Section 4 derives the North Ameri- can temporal $\mathrm{O}_{3}$ trends for each season, and Sect. 5 examines systematic variations in the $\mathrm{O}_{3}$ including seasonal and diurnal cycles and dependence upon a particular air mass flow regime. Finally, Sect. 6 discusses the significance of the derived $\mathrm{O}_{3}$ trends in the context of the European data sets.

\section{Available North American marine boundary layer data sets}

To our knowledge, $\mathrm{O}_{3}$ measurements have been reported from eight, near-sea level sites on the west coast of North America that have been identified as suitable for characterizing $\mathrm{O}_{3}$ in marine air inflow to the continent. Table 1 and Fig. 1 identify site locations, the dates of $\mathrm{O}_{3}$ measurements investigated here, some site characteristics and the source of the data. These eight sites include the five sites discussed by Jaffe et al. (2003) and Parrish et al. (2004a) (Cheeka Peak in Washington and Redwood N.P., Trinidad Head, Point Arena, and Point Reyes N.S. in California), two sites suggested by Oltmans et al. (2006, 2008) (Olympic N.P in Washington and Channel Islands N.P. in California) and Quillayute, Washington where some very early measurements were made (Singh et al., 1978). Also included in Table 1 and Fig. 1 is an inland, continental boundary layer site (Yreka, California) that Oltmans et al. (2006, 2008) suggest is useful for characterizing the marine background $\mathrm{O}_{3}$ flowing into North America.

Most of the $\mathrm{O}_{3}$ measurements at these sites were made using standard UV-absorption analyzers. The National Park Service, the California Air Resources Board and the Global Monitoring Division of the Earth System Research 


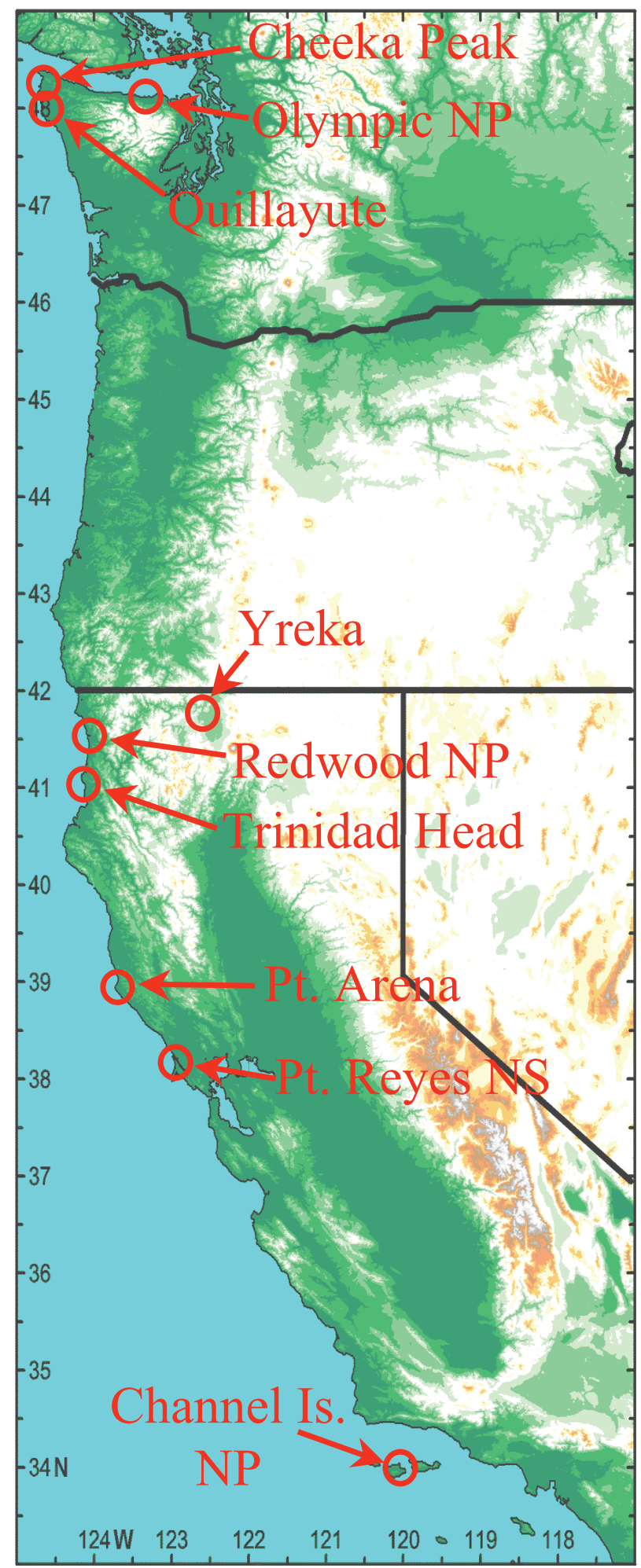

Fig. 1. Map of the North American west coast showing location of surface sites from which the data sets discussed were collected. The colors indicate terrain topography.
Laboratory of the National Oceanic and Atmospheric Administration (NOAA GMD) have each employed a consistent calibration procedure based on US EPA methods. The Pt. Arena field study followed careful data validation procedures. Generally the $\mathrm{O}_{3}$ data sets are believed to be accurate to within $\pm 3 \%$, and the one-hour average data used in this analysis precise to within $\pm 2 \%$ or $1 \mathrm{ppbv}$, whichever is greater. One exception to these limits of accuracy and precision is the earliest data set collected in the mid-1970s at Quillayute, Washington. These are the only measurements that were made using a chemiluminescence technique, and these measurements were made before the US EPA promulgated regulations that defined procedures and approved reference or equivalent methods. Therefore these data are of uncertain quality, and will not be examined in detail. Further, some of the early data from Olympic N.P. were collected by national park staff before the NPS Air Resources Division established the full quality assurance program. Thus, the early data from Olympic N.P. will be examined only with appropriate reservations.

One significant instrumental problem has been identified in the available data sets. NPS personnel report that at the Olympic NP site, the instrument sampling system evidently leaked substantially during the period between maintenance visits on 7 March 2002 and 23 January 2003. Data collected during this period have been eliminated from further consideration.

\section{Analysis of data}

Characterizing $\mathrm{O}_{3}$ in the MBL from measurements conducted at land-based sites presents significant challenges since the measurements necessarily must be conducted in an environment with at least some air-land surface influence. This influence significantly affects the observed ambient $\mathrm{O}_{3}$ through deposition to the ground and other surfaces (most importantly vegetation), $\mathrm{O}_{3}$ destruction by reaction with local emissions, and photochemical $\mathrm{O}_{3}$ production from precursors emitted from land-based sources or even from within the near coastal marine environment (e.g. emissions from coastal shipping lanes.) It is critical that the significance of such effects be investigated, and if significant, their influence eliminated, or at least minimized, in the data sets considered.

Elimination of land effects is most straightforward at island sites. Measurements have been reported from several such sites in the temperate North Atlantic: Bermuda, Barbados, and Westman Island, Iceland (Oltmans and Levy, 1994); Sable Island and Seal Island, Canada (Parrish et al., 1998); and the Azores (Parrish et al., 1998; Honrath et al., 2004). On islands as small and well ventilated as Sable Island (approximately $1 \mathrm{~km}$ wide, by $40 \mathrm{~km}$ long; mean winds usually 10 to $20 \mathrm{~m} / \mathrm{s}$ ) undisturbed marine $\mathrm{O}_{3}$ is generally always sampled regardless of meteorological conditions. Often data from other, larger islands require selection of a clean wind sector 
to isolate the marine signature (e.g. Oltmans and Levy, 1994). Measurements have not been made at comparable island sites in either the eastern North Pacific or eastern North Atlantic, so measurements at coastal, continental sites provide the only land-based approach for characterization of marine $\mathrm{O}_{3}$ near the North American and European coasts. Coastal sites are more appropriate at the west coasts of North America and Europe than at the east coast of a continent, since the prevailing westerly winds assure the prevalence of onshore flow of marine air.

Even with the prevailing onshore flow at the west coasts of North America and Europe, there are synoptic and smaller scale circulation patterns that transport continentally influenced air into the marine environment. To determine trends in marine $\mathrm{O}_{3}$ it is important to screen out measurements that are significantly affected by continental effects. At the Mace Head, Ireland site, both "pollution filtering" and air mass origin as determined from a Lagrangian dispersion model (Simmonds et al., 2004; Derwent et al., 2007) have been shown to be effective for removing continentally influenced data. Here we will simply take the monthly mean $\mathrm{O}_{3}$ data from Mace Head, Ireland (Table 1 of Derwent et al. (2007)) that was selected as baseline air. However, at the North American west coast, complex small-scale circulation patterns, driven both by temperature gradients between the marine and continental environment and by orographic features of the coastal zone, can transport continentally influenced air into the marine environment and can mix air into the MBL from the lower free troposphere. These circulation patterns are likely much more important at the North American west coast than in Europe due to the stronger land-sea temperature gradients and the larger orographic features on the North American coast. Here we will examine effective means for eliminating the continentally influenced measurements at the North American west coast.

\subsection{Selection of marine air by trace species measurements}

The dependence of $\mathrm{O}_{3}$ mixing ratios on meteorological variables and the correlation of $\mathrm{O}_{3}$ mixing ratios with those of other trace species provide two means of identifying continental effects. Trinidad Head is the North American west coast site with the most extensive trace gas measurements (Goldstein et al., 2004; Millet et al., 2004) made during the five-week ITCT 2K2 field study in the spring of 2002 (Parrish et al., 2004b). Continuous measurements of $\mathrm{O}_{3}$ and meteorological variables have been maintained there since that time (Oltmans et al., 2008), and it is also a site included in the Advanced Global Atmospheric Gases Experiment (AGAGE) (Prinn et al., 2000).

Measurements of three trace gases in the Trinidad Head data sets provide particularly useful tracers for North American continental influences. These gases have very different atmospheric sources and sinks so evaluation of the three together provides a robust indication of the importance of the
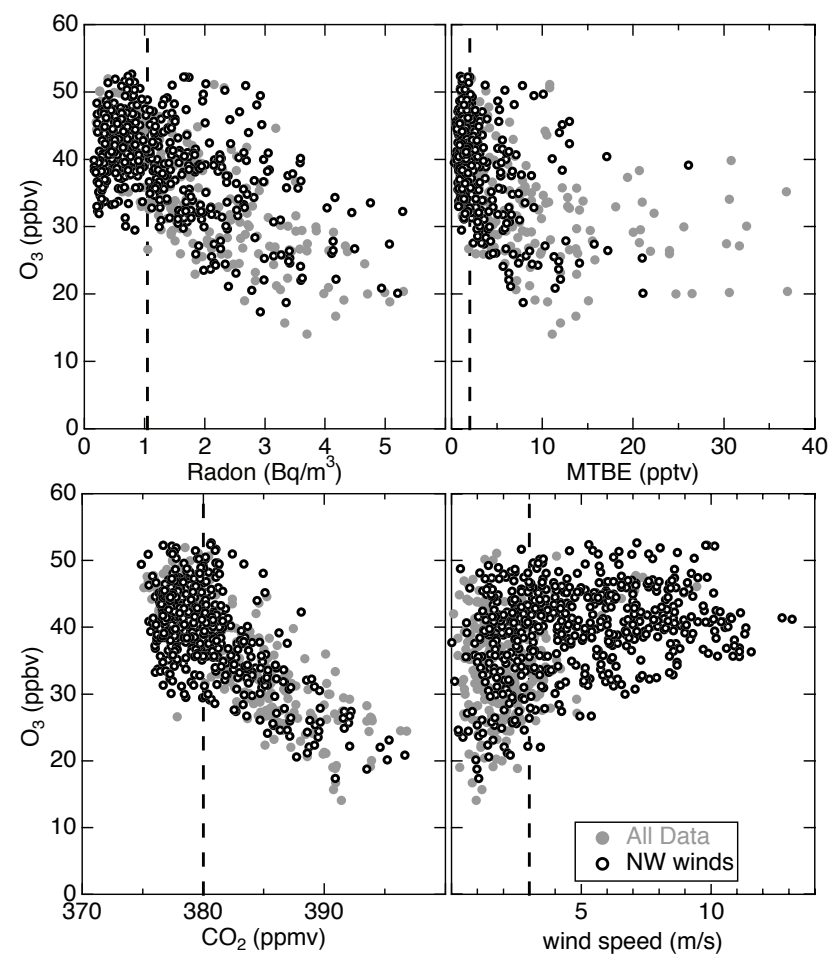

Fig. 2. Dependence of $\mathrm{O}_{3}$ upon parameters that indicate North American continental influence. Data were collected 17 April23 May 2002 at Trinidad Head during the ITCT 2K2 field study (Goldstein et al., 2004; Millet et al., 2004). Open circles indicate one hour-average data collected during northwesterly winds $\left(225^{\circ} \leq\right.$ wind direction $\left.\leq 360^{\circ}\right)$, gray circles indicate other wind directions. The vertical dashed lines indicate the independent variable values selected to separate marine data from those affected by continental influences.

continental influences. Radon is emitted from continental but not oceanic surfaces, and with a radioactive decay halflife of 3.8 days, provides an excellent tracer of recent continental contact of an air mass. Methyl-t-butyl ether (MTBE) (Schade et al., 2002) accounted for 11 to $15 \%$ by volume of the reformulated gasoline in California before its phase out at the end of 2002. With a lifetime of about 4 days at global mean OH concentrations MTBE also provided an excellent tracer of recent continental impact during ITCT $2 \mathrm{~K} 2$. In 2002 MTBE was quite specific to North American influence, since at this time its input to the atmosphere was dominated by US production and use. Further, due to its high water solubility, MTBE is readily taken up by water surfaces and is thus expected to be strongly depleted in the MBL. Carbon dioxide $\left(\mathrm{CO}_{2}\right)$ has sinks (photosynthesis by vegetation) and sources (respiration by vegetation and combustion) that are much stronger in the continental compared to the marine environment. Figure 2 illustrates the correlation of $\mathrm{O}_{3}$ mixing ratios with the mixing ratios of these three gases in the ITCT 2K2 measurements. Higher mixing ratios of radon 
Table 2. Average $\mathrm{O}_{3}$ mixing ratios measured 17 April-23 May 2002 at Trinidad Head during the ITCT 2K2 field study (Goldstein et al., 2004; Millet et al., 2004) under different conditions. All results derived from one-hour average measurements.

\begin{tabular}{llll}
\hline $\begin{array}{l}\text { Selection } \\
\text { Criterion }\end{array}$ & $\begin{array}{l}\text { Average } \mathrm{O}_{3} \pm \\
\text { Standard } \\
\text { Deviation }\end{array}$ & $\begin{array}{l}\text { Diurnal Cycle } \\
\text { Magnitude }^{\mathrm{a}}\end{array}$ & \% Data \\
\hline All data & $38.1 \pm 7.2$ & 11.7 & 100 \\
Radon $\leq 1.05 \mathrm{~Bq} / \mathrm{m}^{3}$ & $42.5 \pm 4.2$ & 4.2 & 48 \\
$\mathrm{MTBE} \leq 2 \mathrm{pptv}$ & $41.5 \pm 4.7$ & 4.0 & 50 \\
$\mathrm{CO}_{2} \leq 380$ ppmv & $42.2 \pm 4.4$ & 5.7 & 51 \\
high, NW winds $^{\mathrm{b}}$ & $40.9 \pm 5.5$ & 5.7 & 43 \\
NW winds & $39.5 \pm 6.5$ & 9.7 & 67 \\
\hline
\end{tabular}

${ }^{\text {a }}$ Units of ppbv $\mathrm{O}_{3}$; Peak-to-peak amplitude of diurnal cycle.

b NW Winds: $225^{\circ} \leq$ wind direction $\leq 360^{\circ}$;

high winds: wind speed $\geq 3 \mathrm{~m} / \mathrm{s}$.

and MTBE (i.e. greater continental influence) correlate with lower $\mathrm{O}_{3}$ mixing ratios, indicating that, at least in spring at Trinidad Head, the primary continental influence on $\mathrm{O}_{3}$ is surface deposition and/or destruction by reaction with local emissions. In continentally-influenced air reaching Trinidad Head in spring, evidently respiration by vegetation and possibly emission by combustion processes dominate the $\mathrm{CO}_{2}$ budget, so that higher mixing ratios of $\mathrm{CO}_{2}$ also correlate with lower $\mathrm{O}_{3}$ mixing ratios.

Inspection of Fig. 2 allows the definition of mixing ratio thresholds of the three tracers that indicate continentally influenced air at that location and time. These mixing ratios are taken to be the upper limits where the measured $\mathrm{O}_{3}$ begins to decrease noticeably. They are indicated by the vertical dashed lines in Fig. 2, and are listed in Table 2. The MTBE and $\mathrm{CO}_{2}$ limits are the same as those utilized by Jaffe et al. (2003) and Parrish et al. (2004a).

The tracer mixing ratio limits for selection of marine conditions provide a mechanism to assess the net effect of continental impacts on the marine $\mathrm{O}_{3}$ in the Trinidad Head ITCT $2 \mathrm{~K} 2$ data set. The measured $\mathrm{O}_{3}$ at tracer mixing ratios less than these limits are taken as characteristic of marine air. Table 2 lists the average and standard deviations of the marine $\mathrm{O}_{3}$ mixing ratios evaluated by the three criteria. The average results of the three tracer criteria indicate that during the spring 2002 period of the ITCT $2 \mathrm{~K} 2$ study, marine $\mathrm{O}_{3}$ averaged $42.0 \mathrm{ppbv}$ with a standard deviation of $4.4 \mathrm{ppbv}$. The three derived averages and standard deviations all agree within $\approx 1 \%$ and $7 \%$, respectively. Notably, each tracer indicates that during about $50 \%$ of the time continental influences significantly affected the measured $\mathrm{O}_{3}$ mixing ratios during the ITCT $2 \mathrm{~K} 2$ study period.

\subsection{Selection of marine air by wind direction and speed}

Here we compare wind and chemical data as criteria for marine air selection at Trinidad Head during the ITCT 2K2 study to inform our later interpretation of data from sites with wind data but no chemical measurements. It is rare to have extensive trace gas data sets available, but many $\mathrm{O}_{3}$ measurement sites collect simultaneous wind data. Figure 2 shows the $\mathrm{O}_{3}$ dependence on wind speed and direction in the Trinidad Head ITCT 2K2 data set, and Fig. 3a shows this dependence in a wind rose format for spring 2007. It is clear that the continental effects (relatively low $\mathrm{O}_{3}$ mixing ratios) are predominately seen at low wind speeds and in sectors other than the prevailing northwesterly wind direction. Two features are notable. First, the continental effects, as indicated by systematically lower average $\mathrm{O}_{3}$, are seen at all wind speeds, but their impact does decrease at higher wind speeds. Second, simply selecting northwesterly wind directions without a wind speed criterion (open circles in Fig. 2) is not effective for isolating marine air. Depleted $\mathrm{O}_{3}$, as well as enhanced mixing ratios of the three continental tracers, are seen in northwesterly winds, particularly at the lower wind speeds. Evidently transport, associated with mesoscale meteorological patterns such as land-sea breeze circulation and various orographic effects, can bring continentally influenced air ashore from the northwest wind sector. Table 2 indicates the resulting average $\mathrm{O}_{3}$ mixing ratios for northwesterly winds, both with and without a wind speed selection criterion. During the ITCT 2K2 study period northwesterly winds occurred about two-thirds of the time, with an average $\mathrm{O}_{3}$ mixing ratio of $39.5 \mathrm{ppbv}$ and a standard deviation of 6.5 ppbv, i.e. $6 \%$ smaller and $15 \%$ more variable than the average marine $\mathrm{O}_{3}$ mixing ratio derived from the three trace gas criteria. Adding the high-wind criterion (wind speeds $\geq 3 \mathrm{~m} / \mathrm{s}$ ) decreased the selected data to $43 \%$ of the total, but significantly improved the agreement of the derived average $\mathrm{O}_{3}$ mixing ratio with the marine average: $40.9 \pm 5.5$ ppbv versus $42.0 \pm 4.4 \mathrm{ppbv}$. In the following analyses, we will utilize simultaneous wind speed and direction data to approximately isolate marine air by selecting only those periods with relatively high, onshore winds.

Coastal orography affects the wind field along the North American coast (e.g. Burk et al., 1999), which, in turn, affects the $\mathrm{O}_{3}$ concentrations observed at coastal sites. This orography-wind- $\mathrm{O}_{3}$ interaction makes the determination of the marine $\mathrm{O}_{3}$ easier in some ways and more difficult in others. One major orographic effect is the wind direction forcing by coastal topography so that the flow has a strong parallel coast component. This component is evident in Fig. 3a where the predominant wind direction is sharply peaked to the north-northwest. This parallel coast flow component ensures that MBL sites situated along the coast, at least north of San Francisco, sequentially sample approximately the same air masses as they are transported down the coast. This helps to ensure that measurements from different MBL sites along 

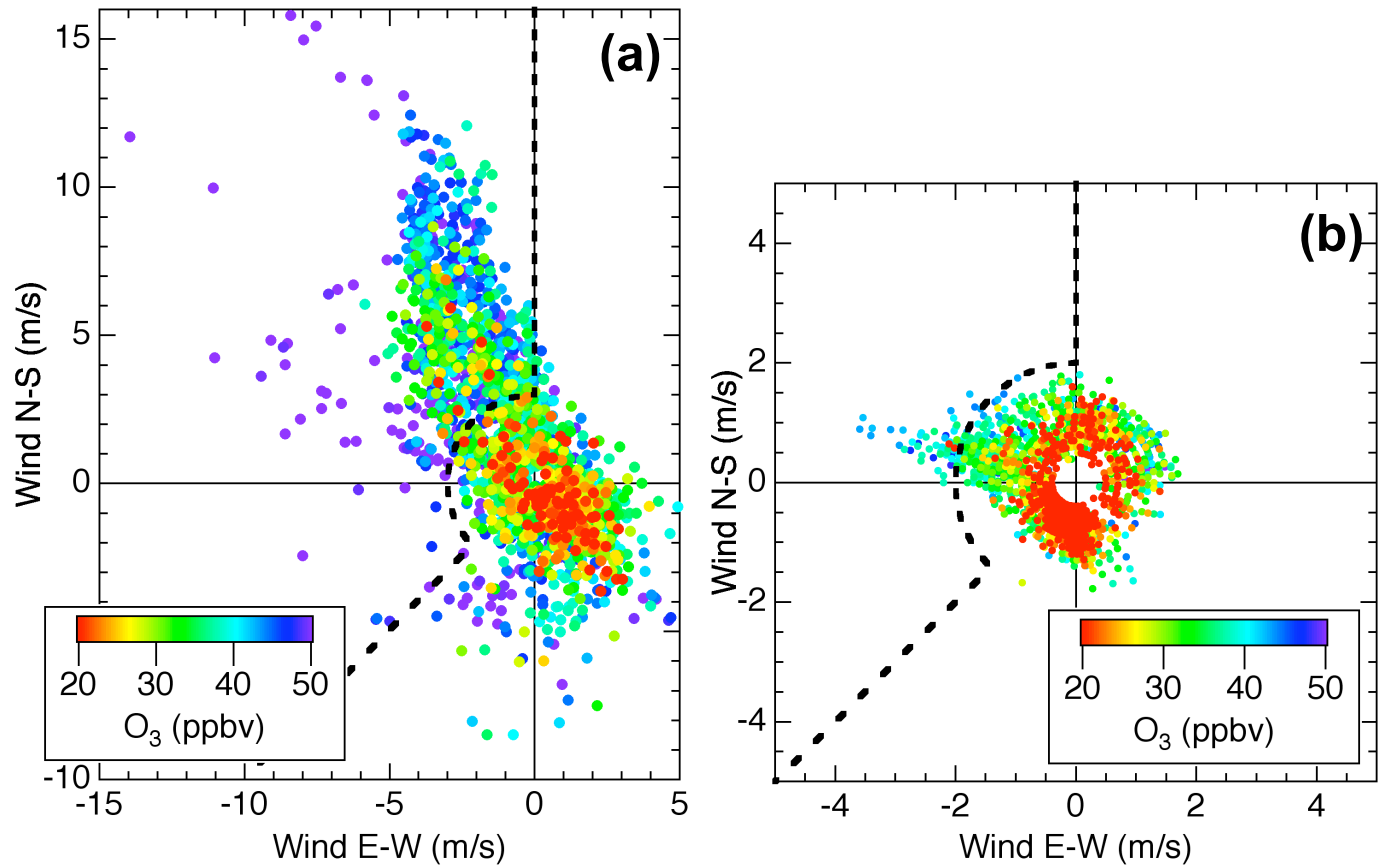

Fig. 3. Wind rose for all one hour-average wind data collected during (a) spring 2007 at Trinidad Head and (b) spring 2003 at Olympic NP. Note the factor of 2 expanded wind speed scale in (b). The symbols are color-coded according to the measured $\mathrm{O}_{3}$ mixing ratios plotted in order of decreasing $\mathrm{O}_{3}$ so that the lower $\mathrm{O}_{3}$ mixing ratios are more clearly visible. To the left of the heavy dashed lines indicates the marine data sector defined here: high (wind speed $\geq 3 \mathrm{~m} / \mathrm{s}$ at Trinidad Head and $\geq 2 \mathrm{~m} / \mathrm{s}$ at Olympic NP), northwesterly winds $\left(225^{\circ} \leq\right.$ wind direction $\left.\leq 360^{\circ}\right)$.

the coast can be directly compared. However, turbulent flow driven by variations in the coastal orography may mix continentally affected air from more northerly coastal locations into the air mass as it moves down the coast. Thus, even under onshore flow conditions with no apparent effects from the land-sea breeze circulation, some continental effects on the observed $\mathrm{O}_{3}$ can be present. However, the good agreement of the wind-selected $\mathrm{O}_{3}$ averages (including the high wind speed criterion) with the trace species-selected $\mathrm{O}_{3}$ averages indicates that the high, northwest wind filter is an effective tool for isolating the marine $\mathrm{O}_{3}$ signature. It should be noted that these orographic effects cannot be resolved by large-scale meteorological data, and trajectories based on these data (e.g. Oltmans et al., 2008). Such trajectories do provide information on the large-scale flow that brings marine air masses to the North American coast, but they are unreliable for selecting against continental effects within the MBL.

A comparison of the derived marine mixing ratios of $\mathrm{CO}_{2}$ in Table 3 with the mixing ratios obtained from NOAA GMD flask data provides a further check of the effectiveness of the wind criteria for the selection of marine data. At Trinidad Head the wind-selected marine air gave an average of $379.4 \pm 2.9 \mathrm{ppmv}$, and the monthly averages derived from the flask data are 378.35 and $378.91 \mathrm{ppmv}$ for April and May 2002, respectively. These flasks are filled to best repre-
Table 3. Average mixing ratios \pm standard deviations measured 17 April-23 May 2002 at Trinidad Head during the ITCT 2K2 field study (Goldstein et al., 2004; Millet et al., 2004) compared for all data and different criteria for selection of marine conditions. All results derived from one-hour average measurements.

\begin{tabular}{llllll}
\hline Species & All data & $\begin{array}{l}\text { High, } \\
\text { NW Winds }\end{array}$ & $\begin{array}{l}\% \\
\text { Data }\end{array}$ & $\begin{array}{l}\leq \text { Selection } \\
\text { Criteria }^{b}\end{array}$ & $\begin{array}{l}\% \\
\text { Data }\end{array}$ \\
\hline Radon $\left(\mathrm{Bq} / \mathrm{m}^{3}\right)$ & $1.4 \pm 1.1$ & $1.2 \pm 1.0$ & 45 & $0.6 \pm 0.2$ & 48 \\
MTBE (pptv) & $4.4 \pm 5.6$ & $2.0 \pm 2.2$ & 45 & $1.3 \pm 0.4$ & 50 \\
$\mathrm{CO}_{2}$ (ppmv) & $381.2 \pm 4.5$ & $379.4 \pm 2.9$ & 47 & $378.0 \pm 4.5$ & 51 \\
$\mathrm{O}_{3}$ (ppbv) & $38.1 \pm 7.2$ & $40.9 \pm 5.5$ & 43 & - & - \\
\hline
\end{tabular}

a NW Winds: $225^{\circ} \leq$ wind direction $\leq 360^{\circ}$;

high winds: wind speed $\geq 3 \mathrm{~m} / \mathrm{s}$

b Selection Criteria given in Table 2 and discussed in text

sent onshore flow of marine air. The average of the windselected marine data are consistent with a small positive bias compared to the flask data, reflecting some continental influence even under high, on-shore wind conditions. This is also consistent with the chemical tracers; the wind selection gives slightly lower $\mathrm{O}_{3}$ than the MTBE or radon selection (Table 2). In the analysis that follows, the effectiveness of the wind criterion will be investigated further. 


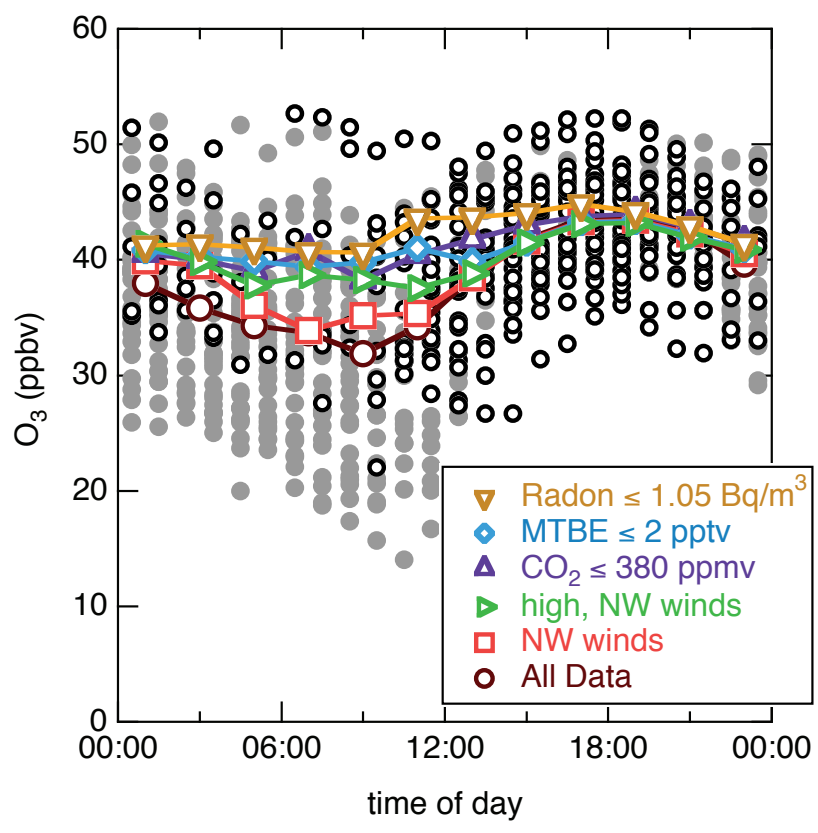

Fig. 4. Diurnal cycle of $\mathrm{O}_{3}$ for 17 April-23 May 2002 measurements at Trinidad Head during the ITCT 2K2 field study (Goldstein et al., 2004; Millet et al., 2004). Gray closed circles indicate all one hour-average data, and black open circles indicate those data collected during high (wind speed $\geq 3 \mathrm{~m} / \mathrm{s}$ ), northwesterly winds $\left(225^{\circ} \leq\right.$ wind direction $\left.\leq 360^{\circ}\right)$. The color-coded, larger open symbols connected with lines indicate two hour-averages of data selected by the criteria annotated.

3.3 Diurnal cycle of ozone mixing ratio - a diagnostic of marine air selection

Here we examine the diurnal cycle of $\mathrm{O}_{3}$ mixing ratio in the MBL as a diagnostic for the success of our marine air selection criteria. Later (Sect. 5.2) we examine the $\mathrm{O}_{3}$ diurnal cycle in the context of the chemical environment of the MBL. A large amplitude diurnal $\mathrm{O}_{3}$ cycle is generally observed at continental surface sites (e.g. Trainer et al., 1987) due to the interaction of the pronounced diurnal evolution of the continental boundary layer depth coupled with the continental influences on $\mathrm{O}_{3}$ discussed previously. During nighttime, the continental boundary layer is generally quite shallow, and $\mathrm{O}_{3}$ is markedly reduced by deposition and reaction with species emitted at the surface. In the vicinity of significant anthropogenic NOx sources and in locations with particularly stable nocturnal boundary layers, nighttime $\mathrm{O}_{3}$ mixing ratios can approach zero. As the depth of the boundary layer grows following sunrise, higher concentrations of $\mathrm{O}_{3}$ are mixed down from layers aloft that were isolated from the boundary layer removal processes during the nighttime. This mixing, combined with the influence of daytime photochemical production of $\mathrm{O}_{3}$, leads to the well-documented afternoon $\mathrm{O}_{3}$ maximum, not only at highly polluted urban sites, but also at much less impacted rural sites.
The $\mathrm{O}_{3}$ diurnal cycle in the MBL is generally much smaller than at continental sites, because the surface deposition and titration loss processes are largely absent, and there is little diurnal evolution of the MBL. In the marine environment remote from emission sources, a small maximum at sunrise is followed by a small minimum near sunset (e.g. see Barbados and Samoa data in Oltmans and Levy, 1994). The afternoon minimum is attributed to daytime net photochemical destruction of $\mathrm{O}_{3}$ in the low NOx, relatively moist and warm environment of the MBL. The net photochemical destruction is balanced by a downward flux of $\mathrm{O}_{3}$ from the relatively $\mathrm{O}_{3}$-rich free troposphere aloft. This downward flux is approximately constant over the diurnal period, which leads to the sunrise $\mathrm{O}_{3}$ maximum following the nighttime hiatus in the photochemical destruction. In the MBL downwind of continental sources, the NOx concentrations may be high enough to support net photochemical production of $\mathrm{O}_{3}$. For example, Parrish et al. (1998) showed that a small afternoon $\mathrm{O}_{3}$ maximum was seen at Sable Island, in closer proximity to the North American NOx sources, while an afternoon $\mathrm{O}_{3}$ minimum was observed at a more remote MBL site on the Azores in the central North Atlantic. Importantly, reported $\mathrm{O}_{3}$ diurnal cycles in the MBL are small (generally < approximately 4 ppbv peak-to-peak). Thus, on the North American west coast, we will take the observation of a relatively strong diurnal cycle, especially with an afternoon maximum, as an indication of significant continental influence upon the measured $\mathrm{O}_{3}$.

The expected differences in the diurnal cycle of $\mathrm{O}_{3}$ in the MBL and at continental sites provide a diagnostic of the success of our criteria for selecting marine air. Diurnal cycles in $\mathrm{O}_{3}$ at the Trinidad Head site calculated for six different criteria are shown in Fig. 4, and the peak-to-peak amplitude of these cycles are given in Table 2 . When all data are included, a relatively large amplitude cycle $(\approx 12 \mathrm{ppbv})$ is apparent. This cycle is largely attributable to the land-sea breeze circulation. During the night and early morning offshore winds bring $\mathrm{O}_{3}$-depleted air to the site from the continent, and during the afternoon the sea breeze brings relatively unperturbed marine air to the site. Marine air selected by each of the three criteria based upon trace species mixing ratios (see discussion above) yield much smaller -4 to $6 \mathrm{ppbv}$ - amplitude diurnal cycles. Selecting periods of high, northwest wind yields a comparably small amplitude cycle 6 ppbv. It is notable that each of these methods for selecting marine air yields a diurnal cycle with an afternoon maximum. At this point it is undetermined whether the afternoon maximum is due to an imperfect selection against continentally influenced air, due to the chemical environment of the Pacific Coast MBL, or due to additional, diurnally varying transport patterns. It should be noted that a selection of winds from off the ocean as utilized by Oltmans et al. (2008) is not adequate for isolating marine air. Including all speeds of northwest winds yields a diurnal cycle (shown in Fig. 4) that is in good agreement with the diurnal cycle shown in Fig. 6 of Oltmans 
et al. (2008) with an amplitude $\approx 10 \mathrm{ppbv}$, which is nearly as large as that derived from the full data set.

\subsection{Comparison of Pacific coast marine boundary layer sites}

To derive decadal trends in average $\mathrm{O}_{3}$ from measurements made for different time periods at different sites, it is important to quantify possible biases between the sites. At least two issues are of concern: first, since the sites to be considered in the temporal trend determinations span $10^{\circ}$ of latitude (approximately $1000 \mathrm{~km}$ ), there may be a spatial gradient in average MBL $\mathrm{O}_{3}$ that could bias the results, and second, the dependence of measured $\mathrm{O}_{3}$ on wind speed and direction may vary between sites. In this section we apply the high speed, northwest wind data selection criteria discussed in Sect. 3.2 to the complete data sets at all four MBL sites with available wind data. As we will show, selection of data by the wind criteria does indeed provide measurements of the average $\mathrm{MBL} \mathrm{O}_{3}$ that are comparable across all four sites.

At the four sites with simultaneous wind and $\mathrm{O}_{3}$ measurements, the dependence of the measured $\mathrm{O}_{3}$ on wind speed is similar, but with some notable differences, particularly at low wind speeds. Fig. 5a shows the average $\mathrm{O}_{3}$ measured as a function of wind speed for northwesterly winds $\left(225^{\circ} \leq\right.$ wind direction $\leq 360^{\circ}$ ) at four sites for all available springtime data. The years of the available data are given in Fig. 5b. As expected from the discussion of Fig. 2, $\mathrm{O}_{3}$ decreases at lower wind speeds at each site due to the increasing effect of continental influence at low wind speeds. This decrease is reasonably similar at three sites, but is significantly greater (i.e. lower measured $\mathrm{O}_{3}$ at lower wind speeds) at Olympic NP, than at the other three sites.

The distribution of measured wind speeds varies markedly between sites. The wind roses in Fig. 3 and the plot in Fig. 5b show that much lower wind speeds occur at Redwood NP and especially Olympic NP than at Trinidad Head and Point Reyes NS. The different wind speed distributions are attributed to differences in the local environments in which the sites and their wind sensors were placed. The two sites with relatively high wind speeds are well exposed to the largescale wind flow. The Trinidad Head site is located below the summit of a promontory that extends out from the coastline, and Point Reyes is located in an unencumbered flat area of the Pt. Reyes Peninsula. In contrast the Redwood NP site is located on the side of a ridge with surrounding trees, and the Olympic NP site is located away from the west coast on the shore of the Juan de Fuca Strait within the city of Port Angeles, Washington, providing more protected wind exposures at these two sites.

The average $\mathrm{O}_{3}$ dependence on wind threshold (Fig. 5c) varies slowly for the Trinidad Head and Point Reyes NP data sets, the two sites with the best wind exposure. The Redwood NP data set, collected at a more sheltered location, shows only a modestly stronger dependence on wind speed.

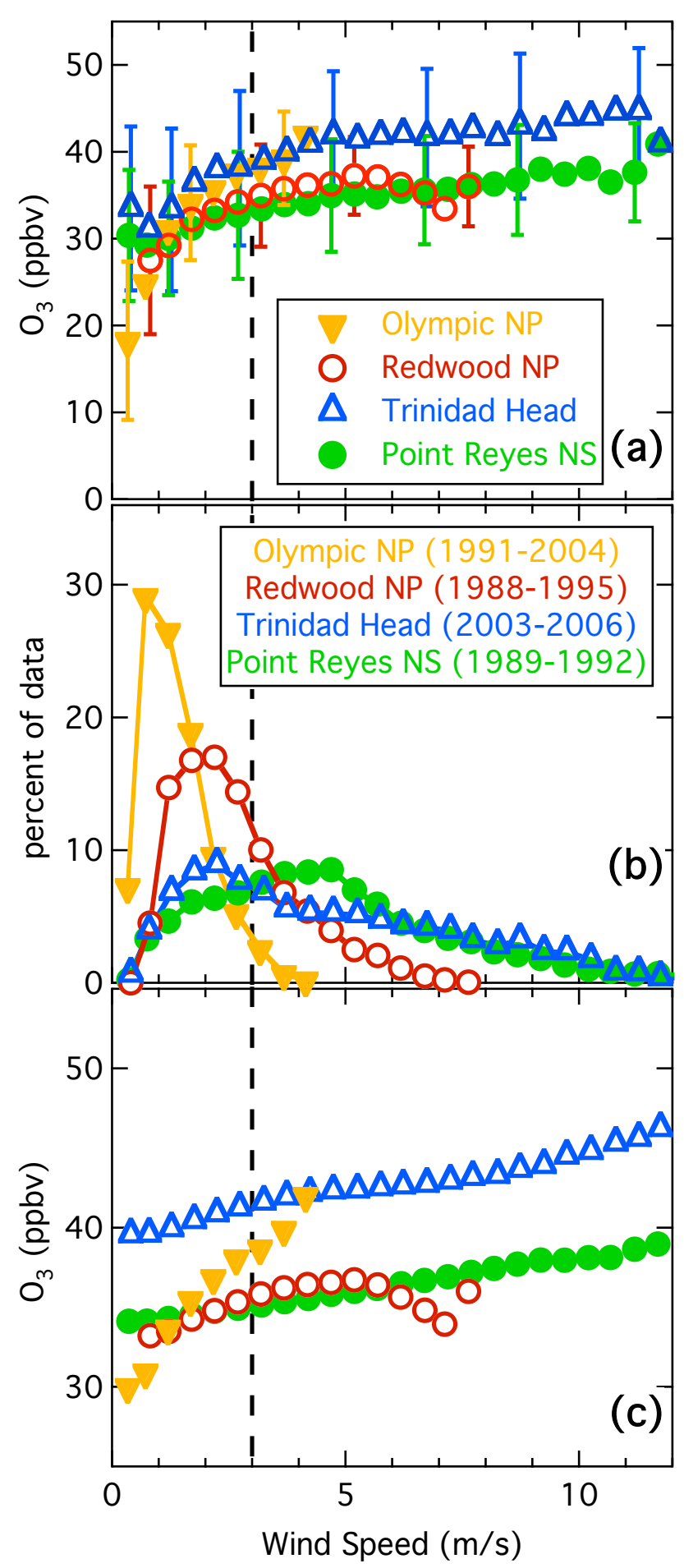

Fig. 5. Springtime $\mathrm{O}_{3}$ dependence on wind speed at four MBL sites. (a) Symbols give average $\mathrm{O}_{3}$ for $0.5 \mathrm{~m} / \mathrm{s}$ wind speed increments; some representative standard deviations of the averages are shown. (b) Percent of data falling in $0.5 \mathrm{~m} / \mathrm{s}$ wind speed increments. (c) Average $\mathrm{O}_{3}$ at all wind speeds higher than the indicated wind speed. All data collected in the indicated years during northwesterly winds $\left(225^{\circ} \leq\right.$ wind direction $\left.\leq 360^{\circ}\right)$ are included. 


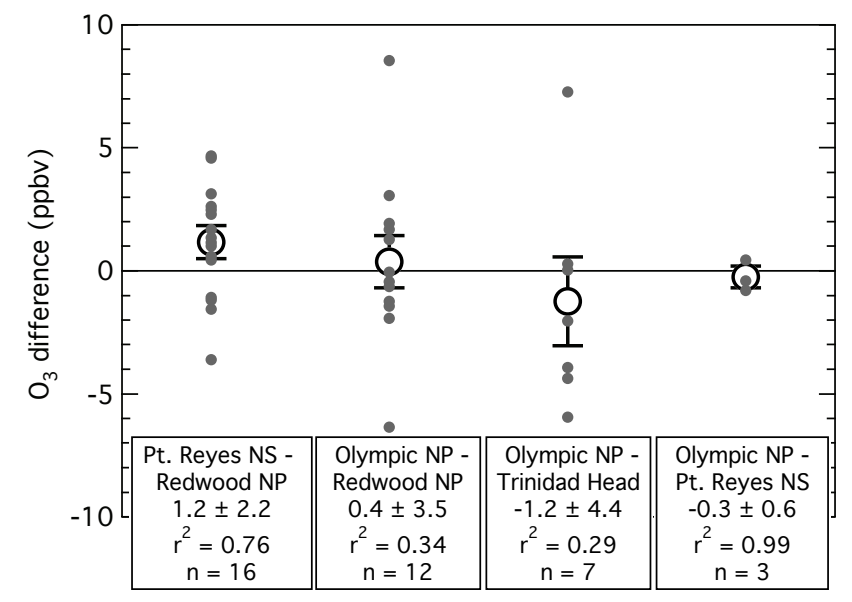

Fig. 6. Differences between simultaneous determinations of average marine $\mathrm{O}_{3}$ mixing ratios at four pairs of sites. Each small grey symbol indicates the difference for one season in one year. Each large open symbol gives the mean difference for the pair of sites with the error bars indicating the one-sigma confidence limit of that mean. The annotations give the sites in each pair, mean differences \pm standard deviations, square of the correlation coefficients for the individual seasonal average $\mathrm{O}_{3}$ mixing ratios that led to the differences, and the number of difference determinations.

(At the upper end of the observed wind speeds, the dependence of $\mathrm{O}_{3}$ concentration becomes more variable due to decreasing frequency of higher wind speeds.) Compared to the other three sites, at Olympic NP, with a much more protected wind exposure (Fig. 5b), the average $\mathrm{O}_{3}$ depends much more strongly on wind threshold (Fig. 5c). This stronger dependence is attributed to a much stronger continental influence arising from the location of the site within Port Angeles, a city with a population of 20000 and the major highway in the region. At low wind speeds, reaction of $\mathrm{O}_{3}$ with local anthropogenic NO emissions is particularly effective in reducing $\mathrm{O}_{3}$. Clearly the Olympic NP site is much more impacted than the other three sites, and its suitability for characterizing marine mixing ratios of $\mathrm{O}_{3}$ requires further discussion below.

Using wind data to select time periods to characterize marine $\mathrm{O}_{3}$ requires a balance between two competing concerns: the desire to retain as much data as possible to achieve a statistically precise measure of the average $\mathrm{O}_{3}$ mixing ratio, and the need to eliminate as fully as possible the continental influences. Jaffe et al. (2003) selected $3 \mathrm{~m} / \mathrm{s}$ (indicated by the vertical dashed lines in Fig. 5) as the best compromise of these two competing concerns. This same selection will be used here with the exception of the Olympic NP site. For this latter site a wind speed threshold of $2 \mathrm{~m} / \mathrm{s}$ is selected since winds above this speed are relatively infrequent (Fig. 5b). It should be noted that the relationships shown in Fig. 5 are similar in other seasons, except that higher wind speeds are less frequent in autumn and winter, compared to spring and summer. Table 4 summarizes the percent of time that winds satisfy the
Table 4. Percentage of time during each season that data satisfy high, NW wind selection criteria ${ }^{a}$ for full data sets. All results derived from one-hour average measurements.

\begin{tabular}{lllll}
\hline Site & Winter & Spring & Summer & Autumn \\
\hline Olympic N.P. & 2.4 & 6.7 & 7.5 & 3.4 \\
Redwood N.P. & 3.3 & 13 & 10 & 5.8 \\
Trinidad Head & 13 & 30 & 29 & 20 \\
Point Arena $^{b}$ & - & 61 & - & - \\
Point Reyes N.S. $^{24}$ & 49 & 55 & 34 \\
\hline
\end{tabular}

a $225^{\circ} \leq$ wind direction $\leq 360^{\circ}$; wind speed $\geq 3 \mathrm{~m} / \mathrm{s}$, except $\geq 2 \mathrm{~m} / \mathrm{s}$ at Olympic N.P.

b data from 14 days in 1985

selection criteria in each season at each site. Such periods vary from quite infrequent (only 2 to $6 \%$ of the time in autumn and winter at the two more protected sites) to nearly one-third of the time in spring and summer at Trinidad Head and about one-half of the time in those two seasons at Pont Reyes NS.

Since the Olympic NP data site has the longest, continuous data set (over 23 years) in the MBL at the west coast of North America, it is important to include those data in the analysis. However, its location away from the west coast itself and the relatively few data that can be considered due to its protected location raise concerns regarding the representativeness of that data set. Although this site location is far from optimal, Fig. 3b shows that the high winds occur from the west-northwest, which is the orientation of the Juan de Fuca Strait. Hence, the $\mathrm{O}_{3}$ mixing ratios selected by the wind criteria do represent direct Pacific airflow through the Juan de Fuca Strait to the site. Such flow does occur only a small fraction of the time. For example, during spring 2003 (the data included in Fig. 3b) only $72 \mathrm{~h}$ of $\mathrm{O}_{3}$ data meet the wind selection criteria. This corresponds to $3.2 \%$ of the total hours in that 3-month period and $3.6 \%$ of the measurement time covered by the available data. However, the diurnal land-sea breeze cycle plays a significant role in determining wind speeds with the high, northwest winds occurring predominately for a few hours in the afternoon on many days. Those $72 \mathrm{~h}$ of selected data represent 17 different days in all three months of the season. While it would be desirable to have measurements available from all days, the 17 days with suitable data nevertheless provide a reasonably representative sample of days, a sample that compares favorably with the once per week schedule often employed by the few intensive sites conducting $\mathrm{O}_{3}$ sonde launches. These considerations indicate that the Olympic NP data set does provide a valuable characterization of $\mathrm{MBL} \mathrm{O}_{3}$.

It is notable in Fig. 5a and $5 \mathrm{c}$ that the $\mathrm{O}_{3}$ measured at Trinidad Head for a given wind speed is significantly higher than that measured at Redwood NP and Point Reyes NS, 
while the result from these latter two sites agree well. As will be discussed further below, this difference is primarily due to the different measurement periods at these sites. The Trinidad Head data were collected more than a decade later than the other two data sets, and the decadal trend in marine $\mathrm{O}_{3}$, which is a primary focus of this paper, accounts for this difference.

Comparison of the seasonal average $\mathrm{O}_{3}$ mixing ratio measured at two different sites in the same year provides a means to check for (1) biases between sites, and (2) the confidence limit that can be assigned to the seasonal average $\mathrm{O}_{3}$ at either site. There is only relatively limited overlap in the measurement time periods between the sites considered here. Figure 6 shows the differences in the seasonal average marine $\mathrm{O}_{3}$ simultaneously determined at the four pairs of sites that have simultaneous measurements. The average bias between the sites in each of the four pairs is 1.2 ppbv or less. Only one average bias is statistically significant at the one-sigma confidence level, and none are significant at the two-sigma level. Hence, there is no evidence for a statistically significant bias over the four sites represented in these pairs, which cover the full latitude range of the sites to be used in the next section to derive decadal trends. The scatter of the ratio determinations in Fig. 6 provides a means to estimate confidence limits for the annual, seasonally averaged $\mathrm{MBL} \mathrm{O}_{3}$ mixing ratio measured at each site. The standard deviation of the 38 differences included in the Fig. 6 is 3.1 ppbv. Propagation of error procedures (see, e.g. Bevington, 1969) indicate that the variance (i.e. square of the standard deviation) of a difference between two numbers is equal to the sum of the variance of the two numbers. As a rough guide to assessing statistical fits, we assume that the confidence limits of the $\mathrm{O}_{3}$ averages at all four sites are approximately equal. This implies that the $1 \sigma$ confidence limit for a seasonal average $\mathrm{O}_{3}$ determination in each year is approximately $2.2 \mathrm{ppbv}$. In the following section, this confidence limit will be used to evaluate the goodness of the statistical fits in the determination of decadal trends.

\section{Decadal trends}

Our goal here is to determine long-term $\mathrm{O}_{3}$ trends in the MBL at the west coasts of North America and Europe, and to investigate the seasonal variation in these trends. For Europe, we utilize the monthly mean $\mathrm{O}_{3}$ data from Mace Head, Ireland (Table 1 of Derwent et al., 2007) that were selected as baseline air; three-month seasonal averages are simply calculated from those numbers. For North America, we will examine trends from two separate data sets - the trend from Olympic NP and one composite trend from four sites with shorter records: Redwood NP, Trinidad Head, Point Arena, and Point Reyes NS. Data from these sites will be selected for marine air by means of a high (wind speed $\geq 3 \mathrm{~m} / \mathrm{s}$, except $\geq 2 \mathrm{~m} / \mathrm{s}$ at Olympic N.P.), northwesterly $\left(225^{\circ} \leq\right.$ wind direction $\leq 360^{\circ}$ ) wind window, which Sect. 3 shows is reasonably effective. As discussed below the trends derived from the two separate data sets are consistent, and one, more accurate and precise trend is derived by combining measurements from all five sites into one composite data set.

\subsection{Statistical approach to trends analysis}

The ability to discern temporal trends in $\mathrm{MBL}_{3}$ from the relatively short, decadal time scale data records that are available is limited by two factors: first, our ability to accurately and precisely determine the average $\mathrm{O}_{3}$ mixing ration in each year, and second, the interannual variability in the average $\mathrm{O}_{3}$ between years that systematically differs from the assumed functional form of the temporal trend. To minimize these limitations we improve the precision of the yearly average $\mathrm{O}_{3}$ mixing ratio determination through three strategies. First, elimination of continental influences to the fullest extent possible substantially reduces the variability in the measured $\mathrm{O}_{3}$ (see Figs. 2 and 4). Second, seasonal rather than monthly or shorter period averaging takes advantage of the reduced variability brought by longer-term averages. It should be noted that averaging over seasons and considering the temporal trend in each season separately avoids the "deseasonalization" process employed in some work (e.g. Harris et al., 2001; Jaffe and Ray, 2007), which introduces unneeded complexity and potentially can confound the trend analysis if different seasons exhibit different temporal trends. Finally, inclusion of as much data as possible improves the precision to which the annual average $\mathrm{O}_{3}$ can be determined. Thus, the combination of the data from the five North American MBL sites with available wind and $\mathrm{O}_{3}$ data provides the most precise determination of temporal trends for that continent.

We primarily rely upon the simplest possible functional form for trend determination. For each season, a linear-least squares fit is made to a two-parameter equation:

$\left[\mathrm{O}_{3}\right]=$ slope* $($ year -2000$)+$ intercept

This slope, in units of ppbv/yr, provides the average yearly increase in $\mathrm{O}_{3}$ mixing ratio over the period of the data record, and the intercept provides the interpolated, seasonally averaged $\mathrm{O}_{3}$ mixing ratio in the year 2000. It should be noted that the utilization of a linear fit does not imply that the temporal trend is necessarily linear, and does not imply that the trend was linear before the data period or will continue linearly into the future. 95\% confidence limits are assigned to each parameter as a test of significance. Further, the statistic $\chi_{v}$, which we define here as the square root of reduced chisquare (Bevingtion, 1969), is given. If Eq. (1) adequately fits the data to within ability of the data to determine the average $\mathrm{O}_{3}$ in each year (i.e. the first factor discussed in the preceding paragraph) then $\chi_{\nu}$ approximately equals the confidence limit on the determination of the annual seasonal average $\mathrm{O}_{3}$ mixing ratio. As discussed in the preceding section, this confidence limit is approximately $2.2 \mathrm{ppbv}$ for the 


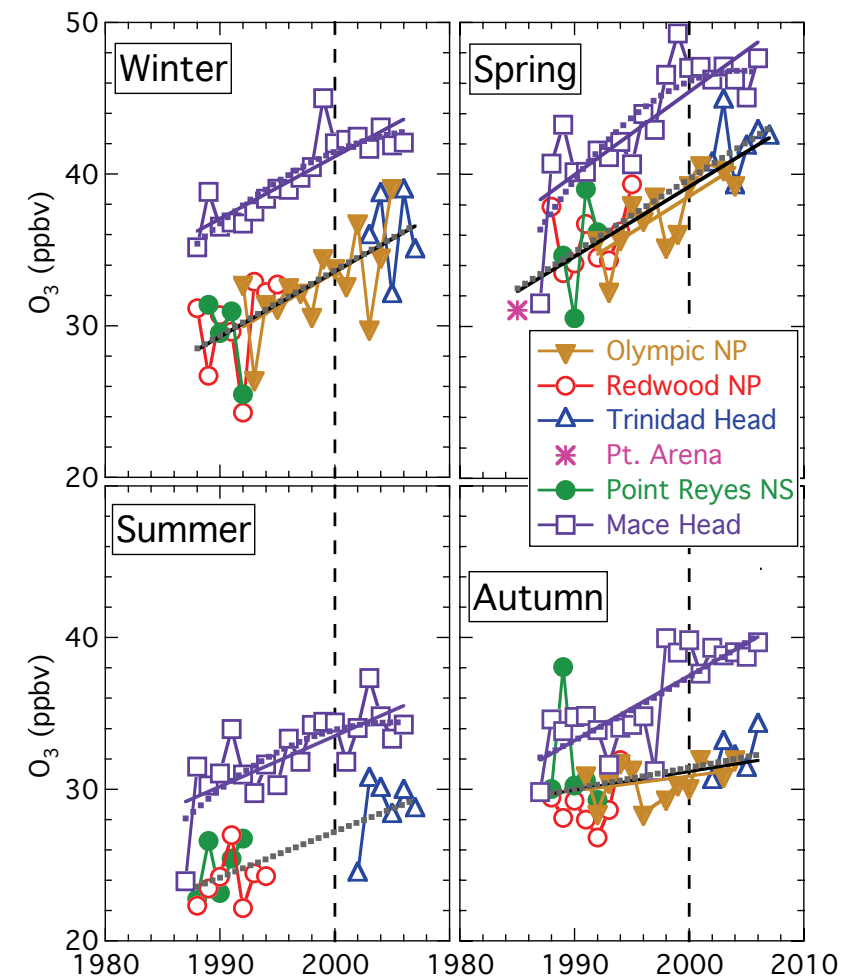

Fig. 7. Comparison of trends in $\mathrm{MBL} \mathrm{O}_{3}$ at the Pacific Coast of North America and at Mace Head, Ireland. Each data point is a seasonal three month average in a given year at the site specified by color and symbol. Linear least-squares fits are given for all Pacific sites (black lines), the Olympic NP data (orange lines), the Pacific sites excluding the Olympic NP data (gray dotted lines), and Mace Head (purple solid lines). Olympic NP data are not available for summer. Second degree polynomial fits (Eq. 2) to the Mace Head data are indicated by the purple dotted lines.

North American data sets. If $\chi_{\nu}$ is significantly larger than the confidence limit, then significant interannual variability or a temporal trend systematically different from the linear dependence in Eq. (1) is expected. In the latter case, the statistical significance of a third parameter, acceleration, is tested:

$$
\begin{aligned}
{\left[\mathrm{O}_{3}\right]=} & \text { slope }_{2000} *(\text { year }-2000)+\text { intercept } \\
& +0.5^{*} \text { acceleration* }(\text { year }-2000)^{2}
\end{aligned}
$$

Here acceleration, in units of $\mathrm{ppbv} / \mathrm{yr}^{2}$, represents the average rate of increase of $\mathrm{d}\left[\mathrm{O}_{3}\right] / \mathrm{dt}$ over the period of the data record and slope 2000 is the value of $\mathrm{d}\left[\mathrm{O}_{3}\right] / \mathrm{dt}$ in the year 2000 . In Eq. (2) the slope 2000 is the rate of increase of $\mathrm{O}_{3}$ in the year 2000 , and the rate of increase changes with time rather than representing the average yearly increase in $\mathrm{O}_{3}$, as was the case in Eq. (1). The factor of 0.5 is required in the last term of Eq. (2) so that the acceleration has the defined meaning, as can be verified by differentiating Eq. (2).
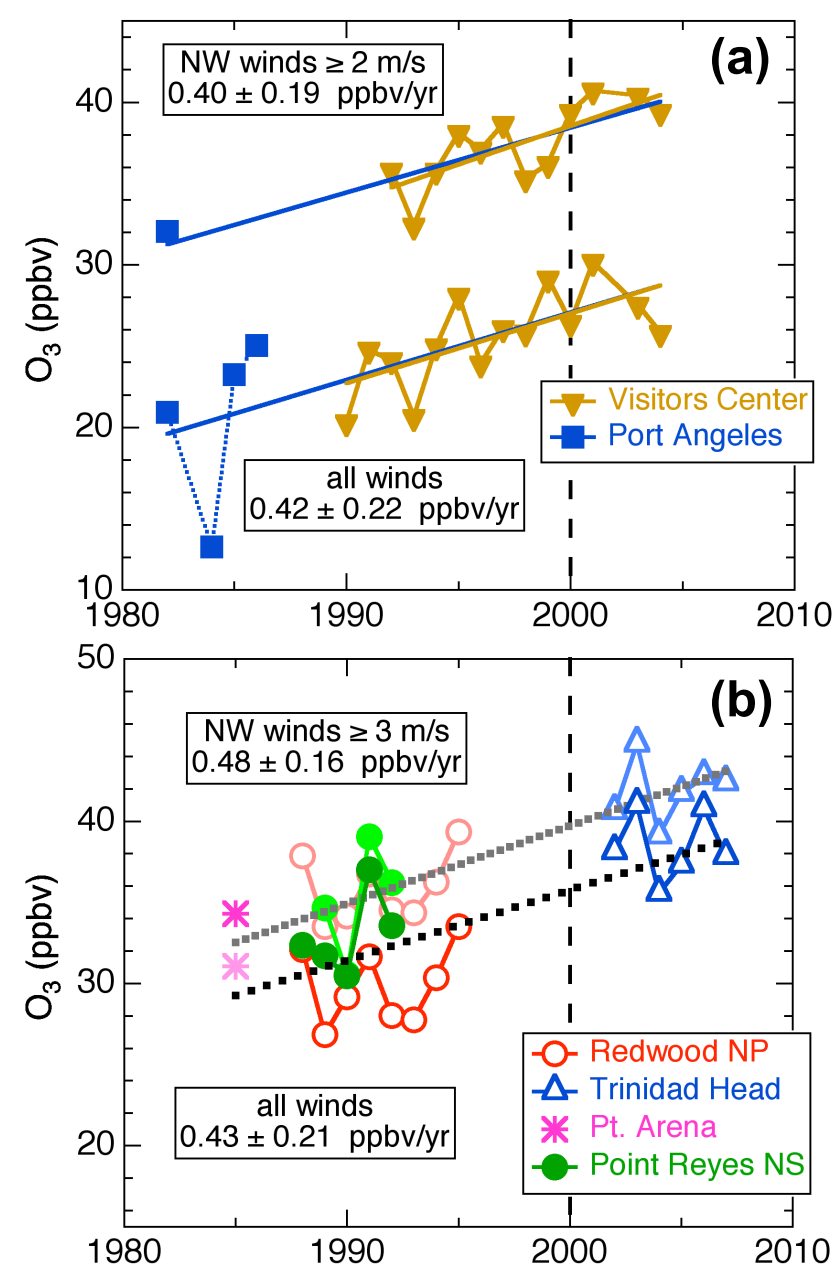

Fig. 8. Temporal trends derived for spring (a) at Olympic NP and (b) for the other MBL sites as a function of wind selection. The Olympic NP Visitors Center data are the same as discussed elsewhere in the paper. The Port Angeles data were collected by the park staff at a nearby site before the National Park service monitoring program was established. In (a) linear least-squares fits are given for both data sets (blue lines) and for the Visitor Center data only (orange lines). The slopes of the former fits are given in the figure annotations. In (b) the wind selected data from Fig. 7 are shown in lighter colors, while the data for all winds are in darker colors.

\subsection{Sea level, marine boundary layer temporal trends}

Significant increases in MBL $\mathrm{O}_{3}$ are found in all west coast North American and European MBL data sets. Figure 7 compares the derived linear temporal trends for the four seasons, and Table 5 gives the parameters of the linear-least squares fits to Eq. (1). At the North American sites there is remarkable agreement between the Olympic NP slopes and intercepts and the corresponding parameters derived for the combined data set constructed from four separate sites. The statistical significance of the derived temporal trends is also 
Table 5. Linear Regression results for decadal trends in $\mathrm{MBL} \mathrm{O}_{3}$ mixing ratios derived from different data sets and different seasons. The $95 \%$ confidence limits are given for the slopes and intercepts.

\begin{tabular}{|c|c|c|c|c|}
\hline Data Set & $\begin{array}{l}\text { All Pacific } \\
\text { Sites }\end{array}$ & Olympic NP & $\begin{array}{l}\text { All Pacific } \\
\text { except } \\
\text { Olympic NP }\end{array}$ & Mace Head \\
\hline \multicolumn{5}{|l|}{ Winter } \\
\hline Slope (ppbv/yr) & $0.43 \pm 0.17$ & $0.45 \pm 0.36$ & $0.43 \pm 0.23$ & $0.41 \pm 0.12$ \\
\hline Intercept 2000 (ppbv) & $33.6 \pm 1.1$ & $33.5 \pm 1.6$ & $33.7 \pm 1.8$ & $41.2 \pm 0.8$ \\
\hline$r^{2}$ & 0.49 & 0.38 & 0.52 & 0.74 \\
\hline$\chi_{\nu}(\mathrm{ppbv})$ & 2.6 & 2.5 & 2.9 & 1.4 \\
\hline \multicolumn{5}{|l|}{ Spring } \\
\hline Slope (ppbv/yr) & $0.46 \pm 0.13$ & $0.48 \pm 0.30$ & $0.48 \pm 0.16$ & $0.55 \pm 0.20$ \\
\hline Intercept 2000 (ppbv) & $39.2 \pm 0.9$ & $38.6 \pm 1.3$ & $39.7 \pm 1.3$ & $45.4 \pm 1.4$ \\
\hline$r^{2}$ & 0.66 & 0.56 & 0.71 & 0.64 \\
\hline$\chi_{v}(\mathrm{ppbv})$ & 2.0 & 1.7 & 2.2 & 2.5 \\
\hline \multicolumn{5}{|l|}{ Summer } \\
\hline Slope (ppbv/yr) & $0.24 \pm 0.16$ & $0.17 \pm 0.40$ & $0.30 \pm 0.13$ & $0.33 \pm 0.16$ \\
\hline Intercept 2000 (ppbv) & $25.7 \pm 1.1$ & $23.9 \pm 1.9$ & $27.2 \pm 1.1$ & $33.5 \pm 1.1$ \\
\hline$r^{2}$ & 0.24 & 0.08 & 0.59 & 0.51 \\
\hline$\chi_{\nu}(\mathrm{ppbv})$ & 2.6 & 2.6 & 1.8 & 2.0 \\
\hline \multicolumn{5}{|l|}{ Autumn } \\
\hline Slope (ppbv/yr) & $0.12 \pm 0.14$ & $0.10 \pm 0.19$ & $0.14 \pm 0.21$ & $0.43 \pm 0.16$ \\
\hline Intercept 2000 (ppbv) & $31.2 \pm 1.0$ & $30.9 \pm 1.0$ & $31.4 \pm 1.8$ & $37.5 \pm 1.1$ \\
\hline$r^{2}$ & 0.11 & 0.12 & 0.12 & 0.62 \\
\hline$\chi_{v}(\mathrm{ppbv})$ & 2.1 & 1.3 & 2.6 & 2.0 \\
\hline \multicolumn{5}{|l|}{ Annual mean } \\
\hline Slope (ppbv/yr) & $0.34 \pm 0.09$ & - & - & $0.39 \pm 0.11$ \\
\hline Intercept 2000 (ppbv) & $32.1 \pm 0.5$ & - & - & $39.3 \pm 0.7$ \\
\hline$r^{2}$ & 0.76 & - & - & 0.74 \\
\hline$\chi_{\nu}(\mathrm{ppbv})$ & 1.1 & - & - & 1.3 \\
\hline
\end{tabular}

quite remarkable in some seasons. For example in spring the average temporal trends (i.e. slopes) for Olympic NP and for the combined data set are significantly larger than zero at the $3 \sigma$ and $6 \sigma$ levels, respectively. These trends are derived from completely independent data sets. Thus, the trend derived by combining all Pacific sites is the best determination of the North American trend, and in spring it is significantly larger than zero at the $7 \sigma$ level. The springtime increase in MBL $\mathrm{O}_{3}$ over the 1985 to 2007 period, which was first reported by Jaffe et al. (2003), is statistically significant to a degree that is essentially beyond question.

The results for Olympic NP are considerably less certain than those from the combined data set. This greater uncertainty arises from the small fraction of data meeting the wind selection criteria ( 2 to $8 \%$ of the time, depending on season), and the greater impact of local emissions due to the location of the measurement site within the Port Angeles city area and its proximity to the major regional highway in that city. In summer, the season of the large majority (nearly $75 \%$ ) of tourist visits to Olympic NP, the local effects influence observed $\mathrm{O}_{3}$ to such an extent that summer data from this site are not included in Fig. 7, although the summer linear regression results are given in Table 5 and these data are included in the calculation of 12 month running means in Sect. 6. In each season, the year 2000 intercept of the linear fit to the Olympic NP data is slightly lower than that obtained from the combined data set, although this difference is not statistically significant except in summer.

Given the small fraction of data meeting the wind selection criteria at Olympic NP, it is of concern that the wind selection criteria could be influencing the derived temporal trends. This may be of concern for the combined data sets as well. Figure 8 compares springtime linear fits to the data meeting the wind selection criteria to the fits to all the data. Included in Fig. 8a are four years of earlier data collected at a different site within the City of Port Angeles, which have not been included in Fig. 7 and the trends listed in Table 5. (Only one of those four years also included wind data.) Three points 
are notable in Fig. 8. First, the derived slopes of linear fits to the data are not strong functions of the selected wind criteria, and the results in Fig. 8 are in statistical agreement with those listed in Table 5. Second, in contrast to the slopes, the year 2000 intercepts are a strong function of the wind selection. The high, northwest wind selection greatly reduces the effects of the local influences, which act to reduce the measured $\mathrm{O}_{3}$, and is particularly important for determining the absolute $\mathrm{O}_{3}$ mixing ratios in the marine air. Third, the earlier data (blue squares in Fig. 8a), while not subjected to the same quality control measures as the later data, do suggest that the increasing trend in MBL $\mathrm{O}_{3}$ began before 1985, the date of the earliest data included in Fig. 7. In summary, the results in Fig. 8 indicate that the wind selection criteria do not strongly influence the derived temporal trends, although they are important for comparing absolute $\mathrm{O}_{3}$ mixing ratios measured at sites with different local influences.

Despite the comparison shown in Fig. 6 and the associated discussion, which establishes that the data collected at the four separate sites can be directly compared, it would be preferable if a long-term record of $\mathrm{O}_{3}$ had been collected at a single site, so that combining data from separate sites would not be necessary. One way to approach this more ideal situation would be to reestablish measurements at the Redwood NP and Point Reyes NS sites, which were terminated in 1995 and 1992, respectively. Measurements for only a few additional years would quickly establish whether the present $\mathrm{O}_{3}$ mixing ratios have exceeded those measured in the early 1990s by the amount suggested by the trends derived in Fig. 7. One quick test of this approach is a direct comparison of the seasonal averages measured at Trinidad Head from 2002-2007 with those measured at Redwood NP from 1988 to 1995 . These sites are both on the California coast within $35 \mathrm{~km}$ of each other. It is straightforward to calculate an average $\mathrm{O}_{3}$ mixing ratio with confidence limit for all of the data measured in each season at each site that satisfy the wind selection criteria. The differences in these averages divided by the number of years between the central time of each data set (13 or 13.5 years) gives an approximate trend, and error propagation techniques provide $2 \sigma$ confidence limits for those trends. The results are highly statistically significant for all seasons, and agree well with the trends listed in Table 5: $0.46 \pm 0.29,0.47 \pm 0.18,0.34 \pm 0.18$, and $0.25 \pm 0.15 \mathrm{ppbv} / \mathrm{yr}$ in winter, spring, summer and autumn, respectively. Of course this agreement is expected, since these data are all included in the composite linear regression. In summary, all of the data sets examined, both by linear regression techniques and this simpler analysis, indicate that statistically robust increases have occurred in the $\mathrm{O}_{3}$ mixing ratio in the MBL adjacent to the west coast of North America.

\subsection{Data available from other sites}

Of the nine sites listed in Table 1, data from only five were included in the trends discussion in Sect. 4.2. Data sets from the other four were excluded for several reasons. For completeness, those reasons are briefly discussed here.

Jaffe et al. (2003) included the Cheeka Peak data in some of the linear fits that they discussed. The $\mathrm{O}_{3}$ measured at this site generally lay above the trends from the other, near sea level sites. This difference is expected because Cheeka Peak is located on a relatively isolated peak at an elevation near $0.5 \mathrm{~km}$. The $\mathrm{O}_{3}$ in the MBL along the North American west coast has a strong vertical gradient (e.g. see Fig. 15 of Oltmans et al., 2008) so that the Cheeka Peak measurements are expected to be several ppbv higher than the sea level mixing ratios. Thus, the Cheeka Peak data cannot be combined with the sea level data sets, and are not discussed further in this paper.

The earliest available data were collected at Quillayute, Washington in 1974-1975 (Singh et al., 1978). If these data were reliable it would be desirable to include them in the trend analysis to extend the time period covered by available data. However, these measurements were made by a chemiluminescence technique, and no information is available regarding calibration and quality control procedures. The US EPA suggests not including data collected before standardized procedures were implemented in 1979 or 1980. Further, no wind data or other measurements are available to eliminate continental effects from the data set. Singh et al. (1978) suggest that these data may have been influenced by transport from Portland, Oregon or from the Seattle-Tacoma, Washington area. Therefore these data are not considered further here.

The California Air Resources Board has made $\mathrm{O}_{3}$ measurements at Yreka, California since 1981. Oltmans et al. $(2006,2008)$ have used these data to suggest that there likely has not been a significant impact of changing background $\mathrm{O}_{3}$ amounts reaching the US west coast. This suggestion clearly conflicts with the conclusions reached in the preceding section, but unfortunately the Yreka site is extremely poorly situated from both regional and local perspectives rendering it unsuitable for characterizing marine $\mathrm{O}_{3}$ levels. Regionally, it is located approximately $125 \mathrm{~km}$ inland in the Klamath River Valley behind the Klamath Mountains, a particularly high section of the North American west coastal ranges. Therefore, the Yreka site always sits within the continental boundary layer, and never directly receives marine air inflow. Marine air is certainly entrained into the continental boundary layer, and trends in the $\mathrm{O}_{3}$ measured at Yreka could still possibly reflect trends in the marine $\mathrm{O}_{3}$ moving inland from the Pacific Ocean. However, the local environment of the site precludes a simple investigation of background $\mathrm{O}_{3}$ trends (see map in Fig. 9). Yreka is well removed from large urban sources, but the site is located within $100 \mathrm{~m}$ of Interstate 5, the major north-south highway along 


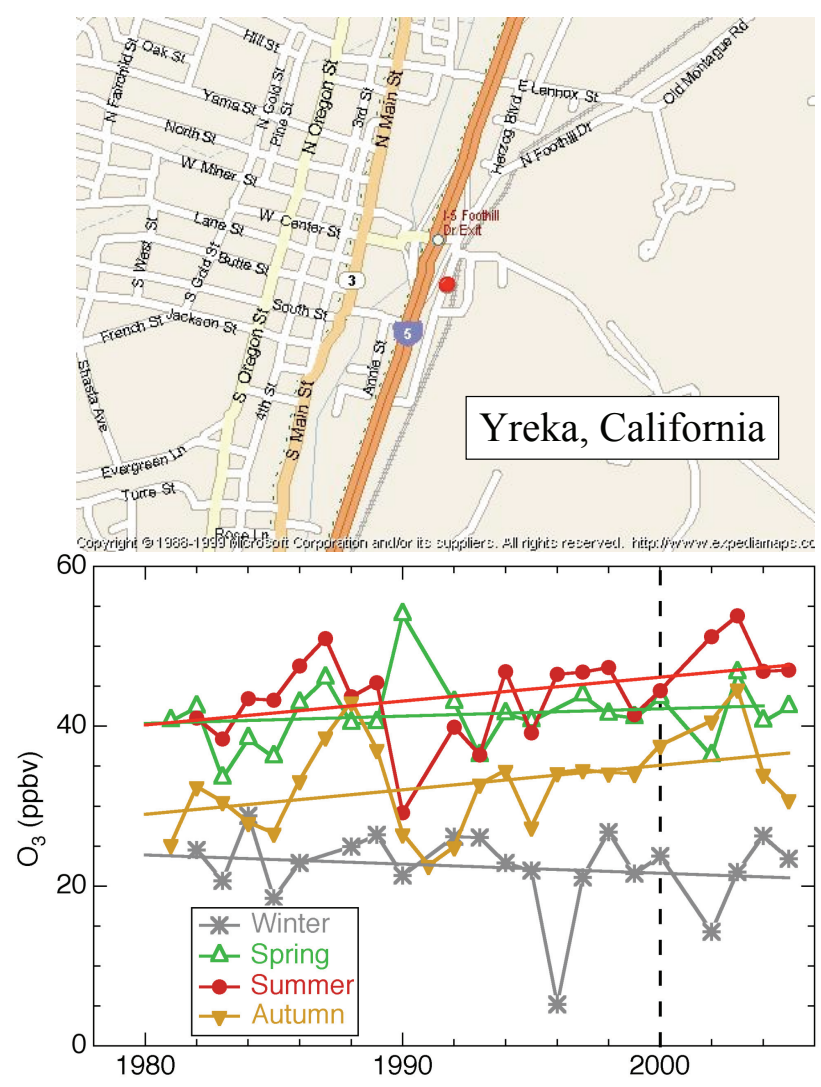

Fig. 9. Monitoring site map (downloaded from CARB website http://www.arb.ca.gov/qaweb/site.php?s_arb_code=47861) and $\mathrm{O}_{3}$ trends analysis for the Yreka, California site indicated by the red circle on the map. The heavy orange line just west of the site indicates the I-5 interstate highway and the light grey line just east of the site indicates a rail line. The parameters of the linear least-squares fits (straight lines) are given in Table 6.

the US west coast. Further, the major US west coast northsouth rail line also passes through the Klamath River Valley approximately $5 \mathrm{~km}$ to the east of the site. The emissions from these transportation sources certainly perturb the $\mathrm{O}_{3}$ mixing ratios at Yreka, both through titration of $\mathrm{O}_{3}$ by fresh $\mathrm{NO}$ emissions and production of $\mathrm{O}_{3}$ under photochemically favorable conditions. Consideration of the temporal trends of these local perturbations is required when evaluating trends in $\mathrm{O}_{3}$ at Yreka. For example, heavy-duty truck traffic, the major source of on-road NOx emissions in the US, increased at an average rate of about $2 \% / \mathrm{yr}$ between 1992 and 2005 (data available from http://www.dot.ca.gov/ hq/traffops/saferesr/trafdata/). An additional difficulty arises from several problems in the archived Yreka $\mathrm{O}_{3}$ data set itself. First, for some periods, particularly near the start of the record, data were recorded with a precision of only $10 \mathrm{ppbv}$, and for others, particularly near the end of the record, data were recorded with a precision of $1 \mathrm{ppbv}$. This changing precision may confound any trends analysis. Second, some data
Table 6. Linear Regression results for mid-day (12:00-18:00 LST) Yreka $\mathrm{O}_{3}$ mixing ratio data set for different seasons. The $95 \%$ confidence limits are given for the slopes and intercepts.

\begin{tabular}{lrrrr}
\hline Season & Winter & Spring & Summer & Autumn \\
\hline Slope (ppbv/yr) & $-0.11 \pm 0.33$ & $0.09 \pm 0.26$ & $0.30 \pm 0.33$ & $0.31 \pm 0.32$ \\
Intercept 2000 (ppbv) & $21.6 \pm 3.2$ & $42.2 \pm 2.9$ & $46.1 \pm 3.2$ & $35.1 \pm 3.3$ \\
$r^{2}$ & 0.03 & 0.03 & 0.15 & 0.15 \\
$\chi_{v}$ (ppbv) & 5.1 & 4.1 & 5.1 & 5.4 \\
\hline
\end{tabular}

sets have measured zero $\mathrm{O}_{3}$ mixing ratios removed. These missing data, particularly when combined with the changing instrument precision, also may confound the trends analysis. Finally, there are periods in the record that appear to indicate improper instrument performance. Oltmans et al. (2008) removed one such period (the year 2001), but several other, shorter periods of suspicious data are also present.

If we ignore the problems in the data archive, we can proceed with a trend analysis for the measured $\mathrm{O}_{3}$ at Yreka. No meteorological data are available to preferentially select periods favorable for elucidating the impact of marine $\mathrm{O}_{3}$, so we will follow the strategy of Oltmans et al. (2008) of selecting data from the later part of the daytime period (12:0018:00 LST). The results of the trend analysis is shown in Fig. 9 and summarized in Table 6. The trends in summer and autumn are positive and nearly significant at the $95 \%$ confidence level, which is in accord with the positive trends noted by Oltmans et al. (2008). However, the absolute $\mathrm{O}_{3}$ mixing ratios in summer at Yreka are nearly twice those measured at the MBL sites (compare intercept 2000 between Tables 5 and 6) The wintertime trend is negative in accord with the discussion of by Oltmans et al. (2008), but the trend derived here is not statistically significant. Notably, the absolute $\mathrm{O}_{3}$ mixing ratios in winter at Yreka are only about $60 \%$ of those measured at the MBL sites, and this difference is statistically significant. These differences between the Yreka and the MBL data clearly indicate that the $\mathrm{O}_{3}$ mixing ratios at Yreka have been strongly modified from the marine environment. In summary, a careful analysis of the Yreka data set might be able to elucidate the behavior of $\mathrm{O}_{3}$ in the heavily impacted transportation corridors in rural regions of the United States, but these data cannot provide any direct information regarding trends in $\mathrm{MBL} \mathrm{O}_{3}$ entering the North American west coast. In particular, statements regarding the impact of changing background $\mathrm{O}_{3}$ mixing ratios reaching the west coast (Oltmans et al., 2006, 2008) cannot be justified on the basis of the Yreka data set.

The Channel Islands NP off the coast of Los Angeles in Southern California is another potentially attractive site for investigating marine $\mathrm{O}_{3}$. Oltmans et al. (2008) present trajectory calculations and suggest that this site is able to provide information on background $\mathrm{O}_{3}$ entering the US. However, these trajectory calculations were based upon meteorological data of relatively coarse spatial resolution $(\geq 200 \mathrm{~km})$, which 

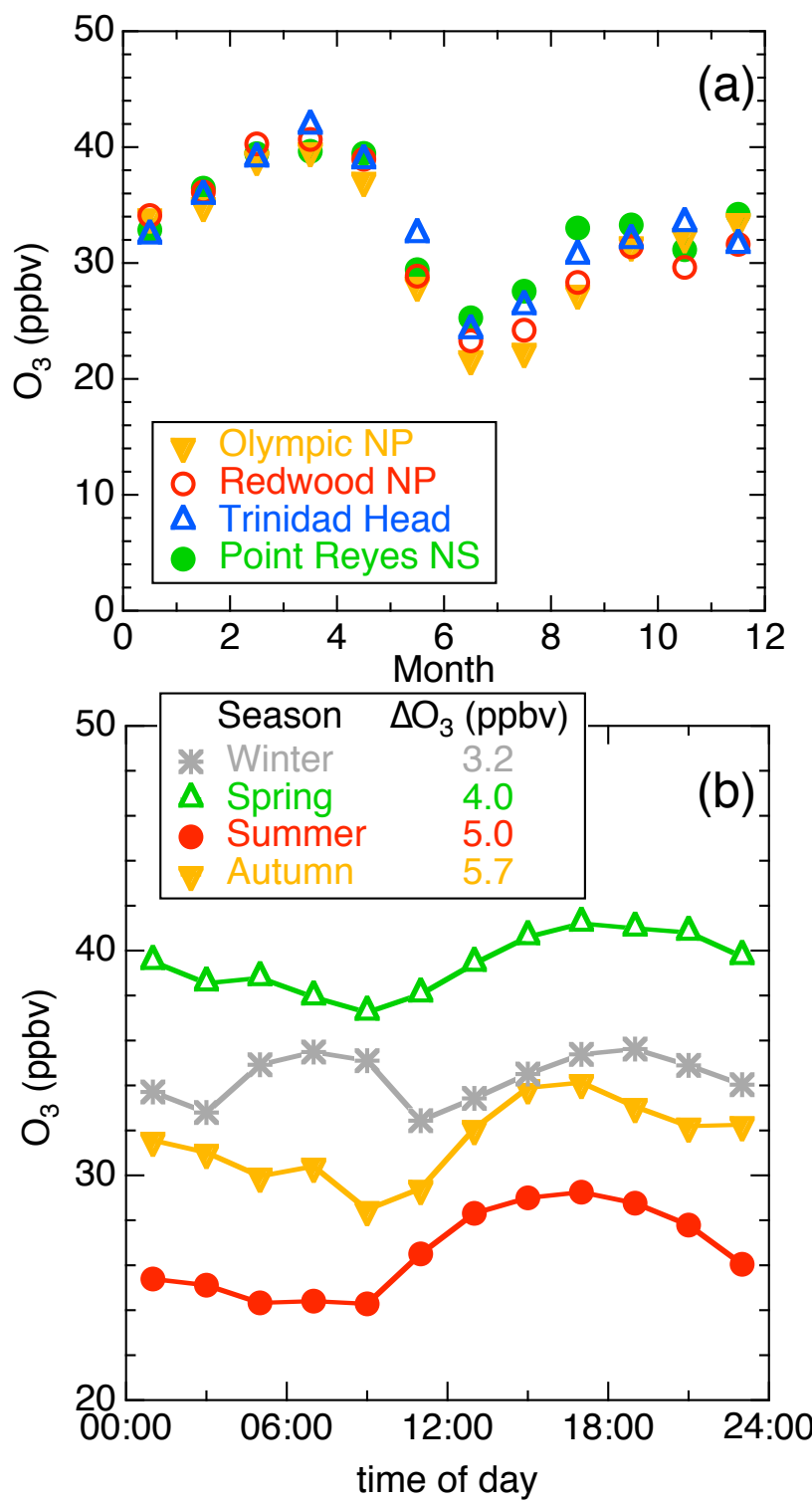

Fig. 10. Seasonal and diurnal cycles of $\mathrm{MBL} \mathrm{O}_{3}$ derived from the data sets collected at the four sites indicated in the figure annotation. The decadal trends were removed from the data before deriving these cycles by correcting each year's data to the reference year 2000 according to the temporal trends given in Table 5. The diurnal cycles are averages of the cycles derived for Trinidad Head and Point Reyes NS.

is unable to resolve the complex circulation patterns that are prevalent along the North American west coast south of San Francisco. These complex patterns, which have spatial scales of $10 \mathrm{~s}$ of km, include the "Catalina Eddy" (Mass and Albright, 1989; Skamarock et al., 2002), and effectively circulate heavily impacted continental air from the Los Angeles urban area into the vicinity of Channel Islands NP. Without detailed mesoscale meteorological modeling of the flow to this site, it will be difficult to glean information on unper- turbed marine $\mathrm{O}_{3}$ mixing ratios. Data from this site will not be considered further here.

\subsection{Nonlinearity of temporal trends}

Derwent et al. (2007) have shown that at Mace Head the temporal trends have decreased to the point that the baseline $\mathrm{O}_{3}$ mixing ratios have approximately stabilized in the years since 2000. This behavior is evident in Fig. 7 and quantified by the fits to Eq. (2) that are included as dotted purple lines in those plots. In all seasons except autumn, the acceleration term is negative ( -0.03 to $-0.07 \mathrm{ppbv} / \mathrm{yr} / \mathrm{yr}$ ) with statistical significance at the 79 to $93 \%$ confidence level. In contrast, the MBL trends at the North American west coast show no statistically significant indication of non-linearity.

\section{Systematic variations in marine boundary layer ozone}

Besides the decadal scale temporal trends discussed in Sect. 4, there are seasonal and diurnal cycles as well as systematic variations with synoptic scale flow conditions that are all relevant to our understanding of $\mathrm{O}_{3}$ in the MBL. Our goal in this section is to investigate those variations. To compare results from data sets collected over different time periods from different sites, all of the data collected within the wind criteria for marine air selection were detrended by subtracting from each $\mathrm{O}_{3}$ measurement a term equal to slope* (year-2000), where the slope is taken from the first column of Table 5. In effect, this adjusts the data to what would have been measured if all data had been collected in the year 2000.

\subsection{Seasonal cycles}

The seasonal cycles derived from the four MBL data sets that cover all seasons are shown in Fig. 10a. The seasonal cycles derived from all four data sets are in excellent agreement, although the summertime results from Olympic NP are somewhat lower due to the difficulty of eliminating local effects at that site in that season. This close agreement again emphasizes the comparability of the measurements made at the different sites. The cycles in Fig. 10a are in good agreement with the seasonal cycles shown in Fig. 18 of Oltmans et al. (2008), although the present results are somewhat lower in magnitude than most of the years included there. This difference arises because the present results represent the year 2000, while the Oltmans et al. (2008) cycles represent the different years 2002-2007.

\subsection{Diurnal cycles}

It is difficult to accurately determine the diurnal cycle of marine $\mathrm{O}_{3}$ from measurements made at a surface site on shore. Figure 10b shows approximate diurnal cycles in each 
of the four seasons. These cycles were derived from the detrended, marine selected data sets from Trinidad Head and Point Reyes NS, the two sites with the best exposure to the prevailing winds. The cycles are the average of the separate cycles from the two sites, which agreed well, but had greater scatter in the 00:00 to 09:00 LST period when the occurrence of selected winds was infrequent (see Fig. 4). The diurnal cycles in Fig. 10b are less than half the peak-to-peak amplitude of the diurnal cycles shown in Fig. 6 of Oltmans et al. (2008), which is due to the more effective removal of continental effects by the wind selection criteria employed in this work.

The magnitudes of the diurnal cycles in Fig. 10b are larger than expected for an isolated marine environment without the influence of transported $\mathrm{O}_{3}$ precursors. The cause(s) of these diurnal cycles deserve further study. The afternoon maximum could possibly reflect photochemical production from $\mathrm{O}_{3}$ precursors emitted within the MBL, e.g. emissions in the coastal shipping lanes (Chen et al., 2005), or nighttime removal of $\mathrm{O}_{3}$ by reaction with such emissions. The magnitudes of the diurnal cycles (given in the annotation of Fig. 10b) do not change markedly between summer and winter as might be expected of cycles primarily due to photochemical production of $\mathrm{O}_{3}$ within the MBL. Compensation subsidence required for mass balance in the land-sea breeze circulation (e.g. see Pilke, 1984) is another possible explanation. During the afternoon sea breeze portion of the cycle, enhanced offshore subsidence of relatively $\mathrm{O}_{3}$-rich air from above is required to compensate for the enhanced onshore flow, which may explain part or all of the afternoon maximum observed in the diurnal cycle. It should be noted that both of these possible causes are local to the ocean-continent interface and therefore not characteristic of the isolated marine environment. It is likely that measurements at an offshore surface site will be required to fully characterize the diurnal cycle of $\mathrm{O}_{3}$ in the MBL of the eastern North Pacific.

\subsection{Southwest flow events}

One focus of the analysis presented by Parrish et al. (1992, 2004a) was springtime events when synoptic flow brought air with markedly lower $\mathrm{O}_{3}$ mixing ratios to the west coast of North America. Such air masses were transported from the sub-tropical North Pacific to the southwest (see trajectories in Fig. 8 of Parrish et al. (1992), and were responsible for the lowest $\mathrm{O}_{3}$ mixing ratios observed in the undisturbed MBL. A striking feature of these events has been the generally rapid increase of these minimum $\mathrm{O}_{3}$ mixing ratios. In the 1985 Point Arena field study these mixing ratios dropped to below 15 ppbv (see Fig. 3 in Parrish et al., 1992). These minimum mixing ratios were almost always above $20 \mathrm{ppbv}$ in the Point Reyes NS and Redwood NP data collected in the early $1990 \mathrm{~s}$, and dropped only to $30 \mathrm{ppbv}$ during the ITCT $2 \mathrm{~K} 2$ study in the spring of 2002 at Trinidad Head. Oltmans et al. (2008) report that such events occur in the Trinidad Head record since 2002 at least once each spring, and that the $\mathrm{O}_{3}$ mixing ratios drop to near $30 \mathrm{ppbv}$. The dramatic increase in these minimum observed $\mathrm{O}_{3}$ over the past two decades is one of the primary reasons for Parrish et al. (2004a) to hypothesize that the photochemical environment of the springtime North Pacific troposphere has changed over the past two decades from predominately $\mathrm{O}_{3}$ destroying to more nearly $\mathrm{O}_{3}$ producing in response to increased anthropogenic emissions transported from Asia. The data sets collected since 2002 and the analysis of the southwest flow events presented by Oltmans et al. (2008) further support that hypothesis.

\section{Discussion and conclusions}

The dependence of $\mathrm{O}_{3}$ on continental tracers (Sect. 3) demonstrates that to effectively study marine $\mathrm{O}_{3}$ from coastal surface sites, continental influences must be removed, even when measurements are made at a site exposed to direct inflow from the marine environment. For example, during the spring 2002 period of the ITCT 2K2 study at Trinidad Head, a MBL site on the northern California coast, the average results of three tracer criteria designed to isolate marine air yielded average marine $\mathrm{O}_{3}$ mixing ratios of $42.0 \mathrm{ppbv}$ with a standard deviation of $4.4 \mathrm{ppbv}$. The three derived averages and standard deviations all agree within $\approx 1 \%$ and $7 \%$, respectively. Notably, each tracer indicates that during about $50 \%$ of the time continental influences significantly affected the measured $\mathrm{O}_{3}$ mixing ratios. It is not adequate to simply select a wind direction window, a time of day window or trajectories based upon coarse resolution meteorological data. However, wind criteria - high (wind speed $\geq 3 \mathrm{~m} / \mathrm{s}$ ) northwest $\left(225^{\circ} \leq\right.$ wind direction $\left.\leq 360^{\circ}\right)$ winds - were shown to give results that are in reasonable accord with the tracer criteria. Data sets from all available MBL sites along the west coast of North America were selected according to the wind criteria and systematic temporal variations (diurnal, seasonal, decadal) were examined (Sects. 4 and 5). Isolation of marine air allowed a demonstration of the equivalence of $\mathrm{MBL} \mathrm{O}_{3}$ measurements from the different MBL sites, and allowed the seasonal average for a given year to be defined for a given measurement site with a 1 sigma confidence limit of about 2.2 ppbv. By combining the $\mathrm{O}_{3}$ measurements available from five MBL sites, decadal temporal trends of $\mathrm{MBL} \mathrm{O}_{3}$ were established with high precision.

Jaffe et al. (2003) and Parrish et al. (2004a) presented evidence that the $\mathrm{O}_{3}$ arriving in springtime in marine air from the Pacific Ocean had increased by about 10 ppbv in the two decades from the mid-1980s to the mid-2000s (i.e. an average temporal trend of about $0.5 \mathrm{ppbv} / \mathrm{yr}$ ). That evidence was based upon three independent data sources: a 15-year record of $\mathrm{O}_{3}$ measured at Lassen Volcanic National Park (a rural elevated site in northern California that receives direct inflow from the Pacific), two airborne campaigns conducted off the west coast of California in 1984 and 2002, and observations spanning 18 years from five US west coast MBL 


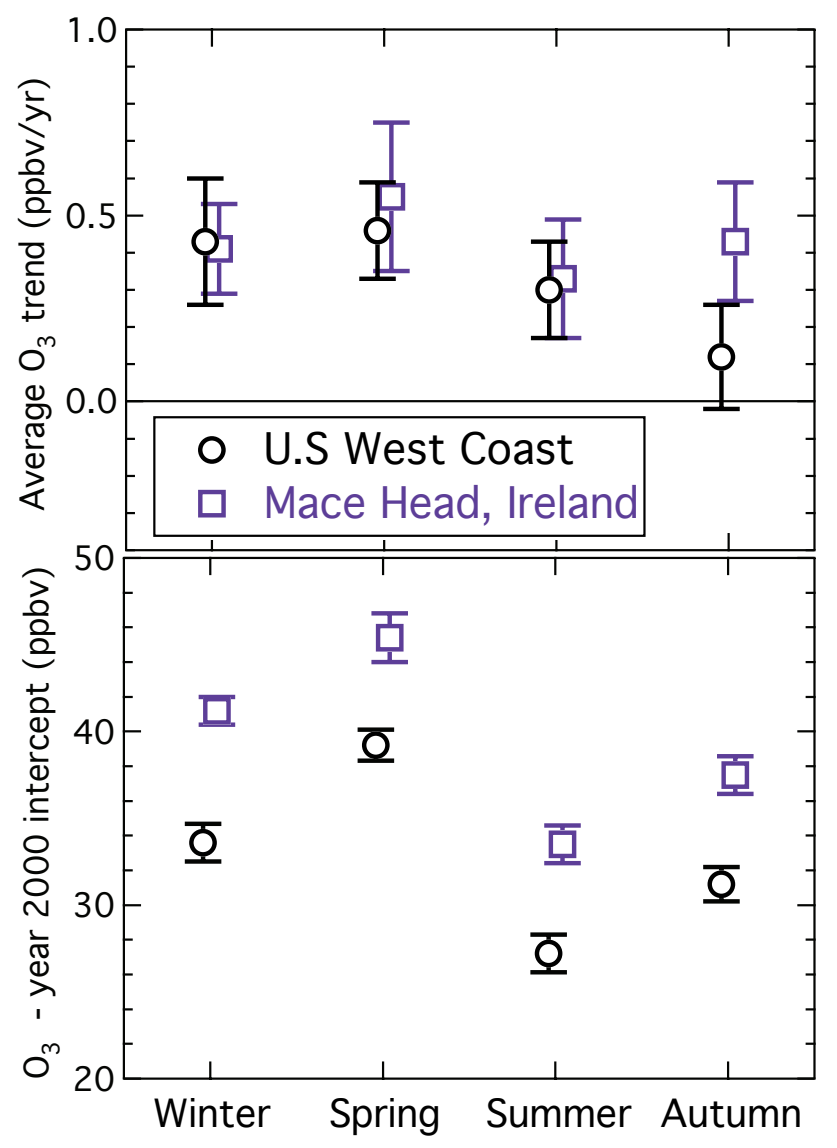

Fig. 11. Comparison of the average annual increase in $\mathrm{O}_{3}$ mixing ratio (upper panel) and the intercept of that trend in the year 2000 (lower panel) for the US West Coast and Mace Head Ireland, a measurement site on the west coast of Europe.

sites. The reevaluation presented here establishes a springtime trend of $0.46 \mathrm{ppbv} / \mathrm{yr}$ with a $95 \%$ confidence limit of $0.13 \mathrm{ppbv} / \mathrm{yr}$, which confirms the trend originally presented by Jaffe et al. (2003) and substantially improves the confidence limits placed on that trend. This improvement comes through inclusion of an additional MBL site at Olympic NP with a 15-year record as well as five additional years of measurements at Trinidad Head. Further, statistically significant trends are found for all seasons except autumn (see Table 5), which does have a significantly slower rate of increase than found for the other three seasons. A future paper will reevaluate data from higher elevation, inland sites that receive direct inflow of marine air, and data sets collected from airborne campaigns, commercial aircraft and sondes. The preliminary results from this second reevaluation are also consistent with the conclusions of Jaffe et al. (2003) and Parrish et al. (2004a) that the trends discussed here are generally characteristic of the free troposphere as well as the MBL.

Comparison of the temporal trend in mean annual $\mathrm{O}_{3}$ in the Pacific MBL to trends reported from continental sites provides some insight into the cause and variability of re-
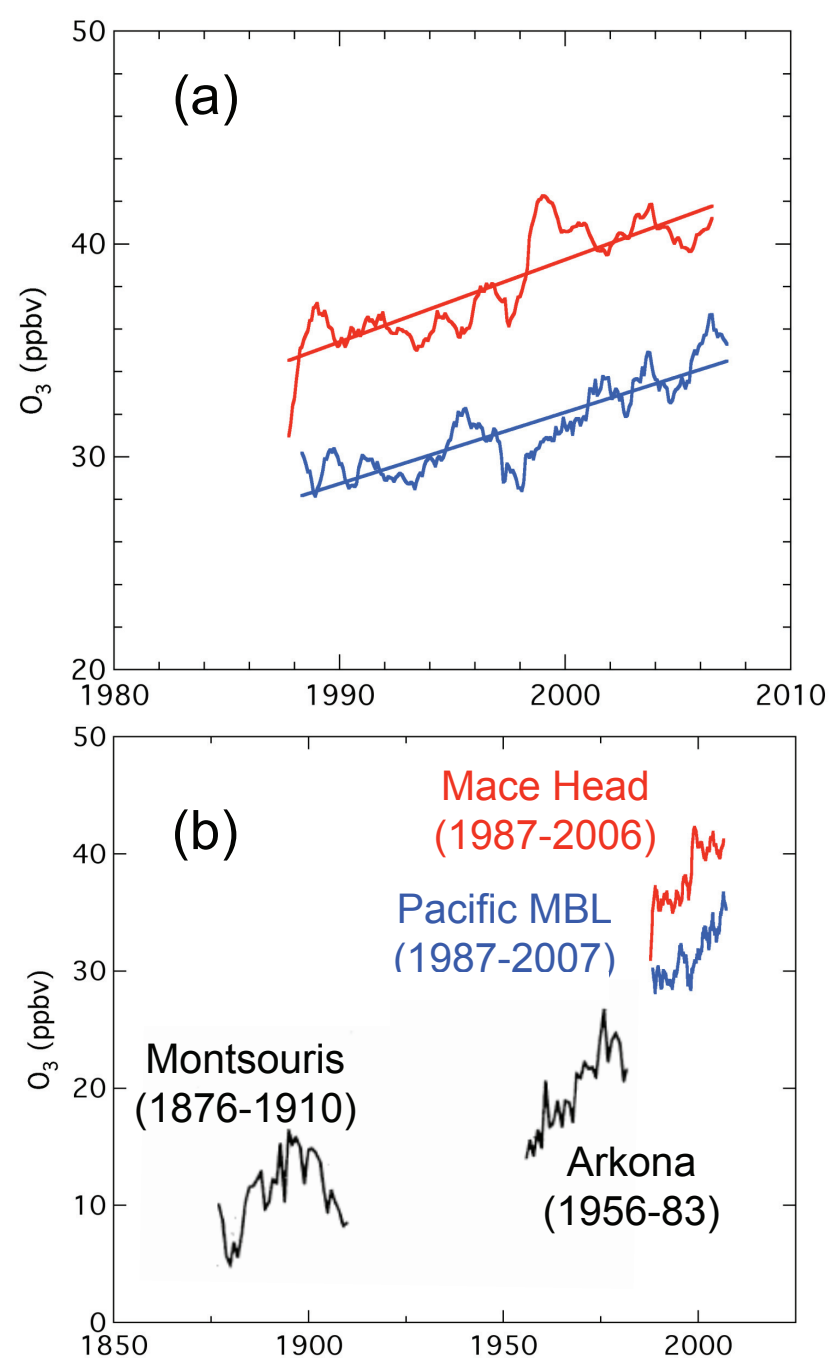

Fig. 12. (a) Comparison of the 12-month running mean $\mathrm{O}_{3}$ mixing ratios from the Pacific MBL sites and Mace Head, Ireland. The parameters from the linear least-squares fits to the annual averages are given in Table 5. (b) Comparison of the running annual mean $\mathrm{O}_{3}$ mixing ratios from this work with the annual averages of earlier measurements reported from two European sites by Volz and Kley (1988).

ported continental $\mathrm{O}_{3}$ trends. Here we derive the temporal trend in mean annual $\mathrm{O}_{3}$ mixing ratio from a linear leastsquares fit of Eq. (1) to twelve month running averages of all data available from the Pacific MBL sites in each month. The parameters of the fit are given in Table 5, where all confidence and goodness-of-fit parameters are based upon one (not twelve) data points per year. The fits are generally as expected from the seasonal fits detailed in Table 5. The $r^{2}$ and $\chi_{v}$ values and the confidence limits on the slopes and intercepts are improved due to the longer period averaging of the annual time scale. The mean annual average Pacific MBL trend $(0.34 \pm 0.09 \mathrm{ppbv} / \mathrm{yr})$ is in excellent agreement with the 
trend reported for Lassen N.P. (0.33 ppbv/yr), the one nearPacific coast site reported by Jaffe and Ray (2007). The trend at the nine rural and remote sites in the western US investigated by Jaffe and Ray (2007) averaged $0.26 \mathrm{ppbv} / \mathrm{yr}$ with a range of 0 to $0.51 \mathrm{ppbv} / \mathrm{yr}$. Evidently the positive temporal $\mathrm{O}_{3}$ trend in air arriving at the North American coast from the Pacific is reflected at the inland sites, modulated by local and regional effects. White Face Mountain (the one continental US site discussed in detail by Oltmans et al., 2006), which is located in the Eastern US, shows no pronounced temporal trend. The positive trend entering western North America likely has been largely obscured by decreasing $\mathrm{O}_{3}$ production within the US driven by decreasing domestic precursor emissions.

The decadal trends in $\mathrm{MBL} \mathrm{O}_{3}$ at the North American west coast present a striking comparison and contrast with those reported for the European west coast. Figure 11 compares the results of the regression analyses from the North American data sets (Table 5) with the results of similar analysis (also included in Table 5) of the Mace Head data reported by Derwent et al. (2007). The trends in the winter, spring and summer seasons compare well at the two locations, while the Mace Head trend is significantly greater in autumn. Even though the trends are similar, the absolute $\mathrm{O}_{3}$ mixing ratios, as indicated by the year 2000 intercept of the linear regressions, are markedly different. The marine air arriving at Europe from the North Atlantic MBL contains $7 \pm 2$ ppbv higher $\mathrm{O}_{3}$ than marine air arriving at North America from the North Pacific MBL, and this difference is the same in all seasons within the indicated $95 \%$ confidence limits. This difference could be due to the net enhancement of background $\mathrm{O}_{3}$ by photochemical production over the North American continent, but a thorough investigation of possible causes should be done through global chemical transport model (GCTM) calculations. There is an additional difference between the two continents - the $\mathrm{O}_{3}$ mixing ratios at the North American west coast show no indication for stabilizing as has been reported for Mace Head (Derwent et al., 2007).

It is of interest to put the present analysis into the context of historical measurements of $\mathrm{O}_{3}$ to the extent that the reported studies allow. Figure 12a compares the running annual means for Mace Head and the Pacific MBL sites, and Fig. 12b compares the $\mathrm{O}_{3}$ mixing ratios that have been reported for boundary layer measurements over the 130 years covered by the available data. The historical data (Volz and Kley, 1988) have been widely interpreted as indicating the change in background $\mathrm{O}_{3}$ that occurred in the decades leading up to the 1980s. The data sets discussed here suggest that this trend has continued at similar rates up to the present time. This comparison can only be semi-quantitative since the sites are not directly comparable - Montsouris was a continental site on the outskirts of Paris, and Arkona is located on the island of Rügen in the Baltic Sea (data originally reported by Feister and Warmbt, 1987). Also, these historical data represent 24-h averages of all measurements, while both data sets discussed in this paper are selected for background conditions. However, the stated uncertainties on the annual averages from all of the data sets are approximately 2 ppbv. Even allowing a larger uncertainty for the different measurement methods employed in the different studies, Fig. 12b clearly indicates that background $\mathrm{O}_{3}$ at northern mid latitudes has increased substantially (by a factor of two to three), and that this increase continues at present, at least in the MBL of the Pacific coast region of North America.

The ability of GCTMs to reproduce observations, particularly observations of tropospheric $\mathrm{O}_{3}$ mixing ratios, provides key tests of those models. Activity 1 of the WCRP-SPARC and IGBP-IGAC initiative - Atmospheric Chemistry and Climate - comprises a 20-25 year hindcast of tropospheric $\mathrm{O}_{3}$ and aerosols. This activity intends to address the following questions: can we understand what has happened with tropospheric chemistry, and in particular $\mathrm{O}_{3}$ and aerosols? Can we replicate the observed changes over the past 20 years? To answer these questions, a comparison of GCTMs is planned. Reproducing the increasing trends in $\mathrm{MBL} \mathrm{O}_{3}$ observed at the west coasts of North America and Europe over the past two decades as well as the difference in the $\mathrm{O}_{3}$ mixing ratios between these two coastal regions will likely present a significant challenge for those models. Further, the ability of models to at least semi-quantitatively reproduce the longerterm trends shown in Fig. 12b should be tested.

Acknowledgements. The authors gratefully acknowledge the helpful discussions of meteorological issues with Paul Nieman and Owen Cooper of the NOAA Earth System Research Laboratory. The Climate and Global Change Program of the National Oceanic and Atmospheric Administration (NOAA) largely funded this research. The authors are grateful to all that provided access to their data. The data from Olympic National Park, Redwood National Park and Point Reyes National Seashore were obtained from the National Park Service (Gaseous Pollutant Monitoring Network, Air Resources Division, Denver, Colorado, 2002; available at http://www.nature.nps.gov/air/monitoring/network.cfm). The data from Yreka, California were obtained form the California Air Resources Board (available at http: //www.arb.ca.gov/aqd/aqded/aqdcddld.htm). The data from Trinidad Head were obtained from the NOAA Earth System Research Laboratory, Global Monitoring Division (available at http://www.esrl.noaa.gov/gmd/dv/ftpdata.html).

Edited by: J. W. Bottenheim 


\section{References}

Bevington, P. R.: Data reduction error analysis for the physical sciences, McGraw-Hill Book Company, New York, 1969.

Burk, S. D., Haack, T., and Samelson, R. M.: Mesoscale simulation of supercritical, subcritical, and transcritical flow along coastal topography, J. Atmos. Sci., 56, 2780-2795, 1999.

Chen, G., Huey, L. G., Trainer, M., Nicks, D., Corbett, J., Ryerson, T., Parrish, D., Neuman, J. A., Nowak, J., Tanner, D., Holloway, J., Brock, C., Crawford, J., Olson, J. R., Sullivan, A., Weber, R., Schauffler, S., Donnelly, S., Atlas, E., Roberts, J., Flocke, F., Hübler, G., and Fehsenfeld, F.: An investigation of the chemistry of ship emission plumes during ITCT 2002, J. Geophys. Res., 110, D10S90, doi:10.1029/2004JD005236, 2005.

Derwent, R. G., Simmonds, P. G., Manning, A. J., and Spain, T. G.: Trends over a 20-year period from 1987-2007 in surface ozone at the atmospheric research station, Mace Head, Ireland, Atmos. Environ., 41, 9091-9098, 2007.

Feister, U. and Warmbt, W. G.: Long-term measurements of surface ozone in the German Democratic Republic, J. Atmos. Chem. 5, 1-21, 1987.

Fiore, A. M., Jacob, D. J., Bey, I., Yantosca, R. M., Field, B. D., Fusco, A. C., and Wilkinson, J. G.: Background ozone over the United States in summer: Origin, trend and contribution to pollution episodes, J. Geophys. Res., 109, 4275, doi:10.1029/2001JD000982, 2002.

Fusco, A. C. and Logan, J. A.: Analysis of 1970-1995 trends in tropospheric ozone at Northern Hemisphere midlatitudes with the GEOS-CHEM model, J. Geophys. Res., 108, 4449, doi:10.1029/2002JD002742, 2003.

Goldstein, A. H., Millet, D. B., McKay, M., Jaeglé, L., Horowitz, L., Cooper, O., Hudman, R., Jacob, D. J., Oltmans, S., and Clarke, A.: Impact of Asian emissions on observations at Trinidad Head, California, during I TCT 2K2, J. Geophys. Res., 109, D23S17, doi:10.1029/ 2003JD004406, 2004.

Harris, J. M., Oltmans, S. J., Tans, P. P., Evans, R. D., and Quincy, D. L.: A new method for describing long-term changes in total ozone, Geophys. Res. Lett., 38, 4535-4538, 2001.

Honrath, R. E., R. C. Owen, M. Val Martı'n, J. S. Reid, K. Lapina, P. Fialho, M. P. Dziobak, J. Kleissl, and D. L. Westphal: Regional and hemispheric impacts of anthropogenic and biomass burning emissions on summertime $\mathrm{CO}$ and $\mathrm{O}_{3}$ in the North Atlantic lower free troposphere, J. Geophys. Res., 109, D24310, doi:10.1029/2004JD005147, 2004.

Jacob, D. J., Logan, J. A., and Murti, P. P.: Effect of rising Asian emissions on surface ozone in the United States, Geophys. Res. Lett., 26, 2175-2178, 1999.

Jaffe, D., Price, H., Parrish, D. D., Goldstein, A., and Harris, J.: Increasing background ozone during spring on the west coast of North America, Geophys. Res. Lett., 30, 1613, doi:10.1029/2003GL017024, 2003.

Jaffe, D. and Ray, J.: Increase in surface ozone at rural sites in the western US, Atmos. Environ., 41, 5452-5463, doi:10.1016/j.atmosenv.2007.02.034, 2007.

Mass, C. F. and Albright, M. D.: Origin of the Catalina eddy, Mon. Weather Rev., 117, 2406-2436, 1989.

Millet, D. B., Goldstein, A. H., Allan, J. D., et al.: Volatile organic compound measurements at Trinidad Head, California, during ITCT 2K2: Analysis of sources, atmospheric composition, and aerosol residence times, J. Geophys. Res., 109, D23S16,
doi:10.1029/2003JD004026, 2004.

Oltmans, S. J. and Levy II, H.: Surface ozone measurements from a global network, Atmos. Environ., 28, 9-24, 1994.

Oltmans, S. J., Lefohn, A. S., Harris, J. M., et al.: Long-term changes in tropospheric ozone, Atmos. Environ., 40, 3156-3173, 2006.

Oltmans, S. J., Lefohn, A. S., Harris, J. M., and Shadwick, D. S.: Background ozone levels of air entering the west coast of the U.S. and assessment of longer-term changes, Atmos. Environ., 42, 6020-6038, 2008.

Parrish, D. D., Hahn, C. J., Williams, E. J., Norton, R. B., Fehsenfeld, F. C., Singh, H. B., Shetter, J. D., Gandrud, B. W., and Ridley, B. A.: Indications of photochemical histories of Pacific air masses from measurements of atmospheric trace species at Pt. Arena, California, J. Geophys. Res., 97(D14), 15883-15901, 1992.

Parrish, D. D., Trainer, M., Holloway, J. S., Yee, J. E., Warshawsky, M. S., Fehsenfeld, F. C., Forbes, G. L., and Moody, J. L.: Relationships between ozone and carbon monoxide at surface sites in the North Atlantic region, J. Geophys. Res., 103(D11), 1335713376, 1998.

Parrish, D. D., Dunlea, E. J., Atlas, E. L., et al.: Changes in the photochemical environment of the temperate North Pacific troposphere in response to increased Asian emissions, J. Geophys. Res., 109, D23S18, doi:10.1029/2004JD004978, 2004a.

Parrish, D. D., Kondo, Y., Cooper, O. R., Brock, C. A., Jaffe, D. A., Trainer, M., Ogawa, T., Huübler, G., and Fehsenfeld, F. C.: Intercontinental Transport and Chemical Transformation 2002 (ITCT 2K2) and Pacific Exploration of Asian Continental Emission (PEACE) experiments: An overview of the 2002 winter and spring intensives, J. Geophys. Res., 109, D23S01, doi:10.1029/2004JD004980, 2004b.

Pilke, R. A.: Mesoscale meteorological modeling, Academic Press, Inc., Orlando, Florida, 1984.

Prinn, R. G., Weiss, R. F., Fraser, P. J., Simmonds, P. G., Cunnold, D. M., Alyea, F. N., O'Doherty, S., Salameh, P., Miller, B. R., Huang, J., Wang, R. H. J., Hartley, D. E., Harth, C., Steele, L. P., Sturrock, G., Midgley, P. M., and McCulloch, A.: A History of Chemically and Radiatively Important Gases in Air deduced from ALE/GAGE/AGAGE, J. Geophys. Res., 105, 17751-17792, 2000.

RETRO: Emission data sets and methodologies for estimating emissions, Report from REanalysis of the TROpospheric chemical composition over the past 40 years, available from: http://retro. enes.org/reports/D1-6_final.pdf, 2007.

Schade, G. W., Dreyfus, G. B., and Goldstein, A. H.: Atmospheric Methyl Tertiary Butyl Ether (MTBE) at a Rural Mountain Site in California, J. Environ. Qual., 31, 1088-1094, 2002.

Simmonds, P. G., Derwent, R. G., Manning, A. L., and Spain, G.: Significant growth in surface ozone at Mace Head, Ireland, Atmos. Environ., 38, 4769-4778, 2004.

Singh, H. B., Ludwig, F. L., and Johnson, W. B.: Tropospheric Ozone: Concentrations and variabilities in clean remote atmospheres, Atmos. Environ., 12, 2185-2196, 1978.

Skamarock, W. C., Rotunno, R., and Klemp, J. B.: Catalina eddies and coastally trapped disturbances, J. Atmos. Sci., 59, 2270 $2278,2002$. 
Staehelin, J., Thudium, J., Buehler, R., Volz-Thomas, A., and Graber, W.: Trends in surface ozone concentrations at Arosa (SwitzerIand), Atmos. Environ., 28, 75-87, 1994.

Trainer, M., Williams, E. J., Parrish, D. D., Buhr, M. P., Allwine, E. J., Westberg, H. H., Fehsenfeld, F. C., and Liu, S. C.: Models and observations of the impact of natural hydrocarbons on rural ozone, Nature, 329, 705-707, 1987. van Aardenne, J. A., Dentener, F. J., Olivier, J. G. J., Klein Goldewijk, C. G. M., and Lelieveld, J.: A $1^{\circ} \times 1^{\circ}$ resolution data set of historical anthropogenic trace gas emissions for the period 18901990, Global Biogeochem. Cy., 15, 909-928, 2001.

Volz, A. and Kley, D.: Evaluation of the Montsouris series of ozone measurements made in the nineteenth century, Nature, 332, 240$242,1988$. 